. G79 





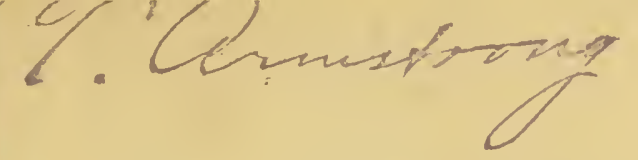

\section{Mr. GREELEY'S LETTERS}

FROM

TEXAS AND 'THE LOWER MISSISSIPPI:

TO WIICI ARE ADDED HIS

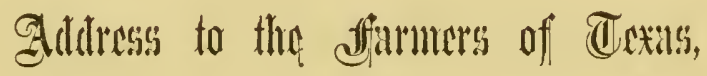

AND HIS

\section{SPEECH ON HIS RETURN TO NEW YORK,}

JUNE 12, 1871.
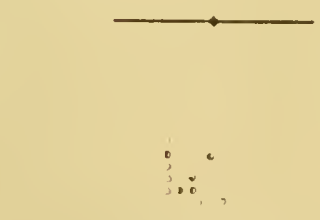

NEW YORK:

TRIBUNE OFEICE.

1871. 


\section{THE LESSON OF OUR CIVIL WAR.}

The New Orleans Price Current-a journal of the intensest Southern proclivities-discusses the visit of Mr. Greeley to the South as follows:

"The industrial doctrines professed by MIr. Greeley have subjugated the South. Not because he professed them-they were planted before his day. They originated with the great De Witt Clinton, who persisted in the execu. tion of a great work of internal improvement which connected the Atlantic with the Lakes. That canal conducted population into the Indian wilderness. It was the pioneer of those other ways which have poured all Europe upon the North-Western territory won by the arms of the Sonthern colonies, and which have naturally brought the votes and arms of that population to the aid of the cities and sections that bestowed these blessings upon them. Mr. Webster, Mr. Carey, Mr. Seward, and Mr. Greeley have been the advocates of the capital, commercial, and mechanical interests. It followed that when the question of inherent rights in the States was referred to the arbitrament of the sword; the one section was on hand with soldiers, ships, arms, food, money, and credit, while the other had courage and a just cause, patriotism and endurance. Now we are far from agreeing with the school in which Mr. Greeley is an eminent professor, that any industry is entitled to special protection at the hands of the Government; but we are satisfied that no people can ever hope to be free that exchange staple productions, worth gold and silver, for commodities which perish in the use; nor who have to send abroad for the guns that they fight with, the food that they eat, and the very clothing that they wear. There can be no doubt but that the command of immigrant numbers, capital, and mechanical skill, with the financial resources of the Government and country, was due to the school of material and industrial development at the North. They received powerful aid from the total want of preparation in these departments at the South. We have always thought that Ames \& Co., the greatest manufacturers of spades, shovels, and axes in the world, did more to conquer a people who had not a manufactory of spades, axes, or shovels, than any general of the Federal army.

"Setting aside, then, the ruinous application which has been made of industrial progress by the Federalists, we have no cause of complaint against the disciples of this school. On the contrary, it is the true duty of the South to cultivate all those industries, the want of which has enslaved her. The foundation of war and conquest was laid when Washington in vain adjured the Southern people to connect the waters of the Chesapeake with the North-Western territory. Mr. Greeley happens to have been a cotemporary of the success of the system founded by Clinton, Adams, and Webster. If there be something in that system to reform or oppose, let us do so; but do not let us commit the inistake of turning our condemnation upon individuals who profess the doctrine.

"There is one topic upon which Mr. irrueley is entitled to the unreserved approval of all who live by land and labor. He has been one of the most intelligent and consistent advocates of agricultural improvement. What he 'Knows about Farming' has become a jocular phrase; but, if he knows as much as he has printed, he possesses no despicable amount of knowledge. It is a little late in the day to sneer at book-farming, when the best minds of the world are engaged in analyzing soil and seed to lessen the labors or increase the profits of the farmer. The Agricultural Department of The New York Tribune contains as much of scientifie and practical knowledge as any other paper, and, as it has a larger circulation than most, must diffuse much of that knowledge."

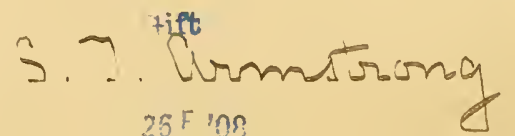




\title{
THROUGH THE SOUTH.
}

\author{
CULTIVATION BY STEAM IN LOUISIANA. \\ [EDITORIAL CORRESPONDENCE OF THE TRIBUNE.]
}

New Orleaxs, May 17.-On our way down through Mississippi, we made the acquaintance of Mr. H. E. Lawrence, a lifelong and successful sugar-planter, who, on learning my anxiety to witness Plowing by Steam (not for show, but as a business), invited us to visit the plantation of his brother, where that style of breaking up the earth is in fashion. Accordingly, a tug-boat was chartered, and some forty or fifty gentlemen, including the Congressman of the lower district, Gen. J. H. Sypher, Collector Casey, Judge Dibble, several Editors, and my traveling companions, Gen. E. A. Merritt, and Charles Storrs, Esq., devoted yesterday to Sugar-planting by Steam.

Magnolia plantation lies some fifty miles below this city, having a front of two miles on the west bank of the river, with the Gulf of Mexico but five miles distant on either hand. Most of the ten-mile strip which here constitutes the County (late parish) of Plaquemine is a reedy marsh, the haunt of alligators, musketoes, dc., which a tempest in the Gulf may submerge at any time; but a fine forest of Live Oak on the rear of this plantation indicates that the surface usually dry is wider at this point than the average. The famous Levees are slight affairs so near the Gulf, where the rise and fall of the mighty stream (here a mile and a half wide) rarely exceeds three feet, and at the nimost is seven. The river-surface is now but two to three feet below that of the Levees, and has recently been two feet higher. Water leaking through the Levee is caught in the substantial ditches that everywhere traverse the plantations, and runs swiftly away till lost under the rank vegetation of the swamps or absorbed by some bayou of the adjacent Gulf. This whole region has of course been formed of the muddy sediment deposited by the Father of Waters wherever the swiftness of its current is arrested. Thus by ten thousand anuual overflows, mainly in A pril or May, 
Lonisiana has been projected far into the Gulf; and the process of making new land at the expense of salt water is still in progress. Though the tide rises eighteen inches at New Orleans, and is felt at Donaldsonville, seventy miles further up, the force of the current keeps the river here wholly fresh at this season, though it is somewhat brackish at times when less water is passing out. That the soil is rich, black, and of unfathomable depth, need not be added. Ditching or deep plowing is constantly unearthing immense cypresses which have been imbedded here for thousands of years-some of them still sound and serviceable.

Mr. Effingham Lawrence, the owner of Magnolia plantation, is a scion of a well-known Long Island family, the son of a good farmer, and. himself invented a plow when but ten years old. Cultivation is not ouly his pursuit but his passion. He came hither while still young, and has planted since his minority. The machinery in his Sugar-House, where he refines more sugar than he makes, has cost $\$ 300,000$, and little of it has been superseded by later and more perfect devices. Of his 3,000 acres, he cultivates 1,000 , which is nearly all that stands well out of water. Some of the most efficient of his former slaves have left him to plant rice on small places below him, where they make $\$ 1,000$ to $\$ 2,000$ each per annum, being superior workers. Most of his ex-slaves chose to remain with him, and some of them are here earning $\$ 40$ per month. His arable acres are divided into tracts or fields of five to ten acres each by deep ditches on the north and sonth, crossed by firm high roads on the east and west. These acres have been sixty or seventy years cultivated, mainly in Cane, and have received little or no fertilization, unless an annual burning the waste stalks or "trash" of the Cane to get rid of it may be called such. Negroes and mules have till recently. furnished all but the brain-power employed.

$\mathrm{Mr}$. Lawrence was accustomed to use teams of eight mules to each plow, and was then able to pulverize but eight to ten inches in depth. Had he not been an experienced and capable plowman, constantly in the field and often between the plow-handles, he could not have got below six inches, even by the aid of all the persuasives known to plantation management. Of course his soil, annually drawn upon by such exhausting crops as Cane and Corn, srew gradually less productive; and he was among the earliest to realize the necessity of bringing Steam to the aid of Agriculture. He had means and credit; he thoroughly understood his business and its needs; he 
visited Europe and scrutinized the working of various Steam Plows; and he concluded that Fowler's machinery, whereof two powerful engines stand at each side of the field and draw the plows back and forth by winding up and unwinding wire-ropes around their respective drums, was the only device adapted to this soft, heavy, easily compacted soil. He bought successively two sets of these machines, the second much heavier and more powerful than the first; and he is now using thirty-horse engines, supplied on his resolute demand, though none so powerful had ever been constructed for plowing till he ordered them. When the Fowlers have done their best for him, he takes the machines into his own shops and directs such modifications as his own experience has suggested. He is confident that we shall soon require sixty-horse engines, and that by their aid dry prairie may be plowed two feet deep at the rate of at least fifty acres per day.

Though the season has been persistently cool and rainy, so that everything 1s backward, and the soil was too wet to be plowed to advantage, yet we fuund, on our unannounced arrival, both sets of plowing machinery in full operation, with none but negro field-hands near them, though an overseer rode from field to field supervising their efforts. Boys of 12 to 14 years, who could not hold a breakingup mule-plow, were running engines as learners, at wages of seventyfive cents each per day. The ground was cane-stubble, heavily ridged or hilled to counteract excess of moisture, with the "trash" of last year's crop lying between the rows and constantly clogging and choking the plows, often requiring the machinery to be stopped in order to clear them. The subsoil-never disturbed till now-is a glutinous clay loam, compacted by sixty years' treading of heavy mule teams, so wet that it came up unbroken, as if it were glue, and about as easy to pulverize as so much sole-leather. So obstinate is it that Mr. Lawrence had reduced each gang of plows to two, lest his engines should be stalled or his wire-ropes broken. These two each cut a furrow sixteen inches wide and fully two feet in average depth : had the surface been level, they would have averaged twenty-six inches. They were drawn across the field ( 576 feet) faster than most men would like to walk. Three men were required to keep them in place, and clear them of the choking "trash," which $I$ would have burned out of their way, though I, had I been planter, would have preferred to have it buried as they buried it. Against all these impediments, each set of machinery was plowing from five 
to six acres per day-plowing them two feet deep, remember, and thus relieving them of the generally superabundant moisture as shallow plowing, or even ordinary sub-soiling, never did and never can. Mr. Lawrence, upon land thus plowed, makes an average of 2,000 pounds per acre of sugar where he formerly made but 800 pounds. And he regards himself as yet on the threshold of Steam Cultivation.

And even this was not the best he had to show us. In other fields, perhaps half a mile distant, other machines were cultivating Cane by Steam. I believe the like of this has not yet been done elsewhere on earth. The rows of Cane are fully seven feet apart; the plants now fully a foot in average height. A locomotive engine stands at either end of the field, moving forward or backward at a touch of the hand of the negro boy standing upon it and looking out for signals. The cultivator is composed of five or six ordinary horse cultivators, enlarged and fixed in a frame, whereof the half that has just stirred the earth to a depth of two and a width of five feet is lifted clear of the ground on reaching the engine which draws it, while its counterpart is brought down to its work by the plowguider stepping upon it. At a signal, the boy at the other end of the field or "land" starts his engine, and begins to wind up his wirerope and uncoil or pay out that of the drum beneath the opposite engine, pulling the cultivators through the earth as they are guided nearer the row that they were kept further from as they passed in the opposite direction. Having thus thoroughly pulverized the space between two rows, by traversing it twice, the engines move forward to the next space and there repeat the operation; and so on till nightfall. Mr. Lawrence assured me that one such thorough working answers for the season; whereas, while tilled by mule-power, every cane-field required working six times per season at intervals of fifteen days. A set of machinery and hands tills about twelve acres per day. I judge the cost of this day's work, including fuel and wear of machinery, ranges from $\$ 25$ to $\$ 30$. This is far below the cost of repeated workings by mule-power, while it is much more efficacious. The land plowed and tilled by steam is far dryer than the rest. Mr. Lawrence considers his thousand acres under tillage worth $\$ 100$ per acre more than they would be but for Steam Culture. He will keep his two sets of Plowing marhinery at work not only throughout each day when the earth is not too sodden, but (by relays of hands) throughout each night also, when the moon serves. 
Steam tillage of growing crops, being a nicer, more critical operation, will be confined to daylight. But the Antumn is here the dry season, therefore most favorable to plowing; and he realizes an immense advantage in this: Thronghout the cane-cutting months of October and November, when all the mules on a plantation are overworked at hauling up cut Cane from the fields to the sugarhouse, so that plowing with animals is impossible, he will have his plowing machinery constantly at work, doing him most excellent service in preparing for next year's crop.

I am quite aware that this letter will not convey any clear idea either of the machinery or the processes enployed in Steam Plowing and Tillage. No sensible man expects to be made acquainted with these otherwise than by personal and careful observation. If I have given any tolerable idea of the results achieved, their cost and their value, I have done all I purposed. I close, then, with an avowal of my confident belief that Mr. Effingham Lawrence has rendered an immense service to American Agriculture, especially that of the Prairie States, by demonstrating the benefits not merely of Steam Plowing but of subsequent Steam Tillage, and that the day is not remote wherein the "barrens" of Long Island and New Jersey, the rich intervales of the Connecticut and the Susquehanna, will be profitably plowed and tilled to a depth of twenty-four to thirty inches by Steam Power, and that far larger and surer crops than those of the past will therefrom be realized.

H. G.

\section{THE LOWER MISSISSIPPI AND THE GULF.}

[EDITORIAL CORRESPONDENCE OF THE TRIBUNE.]

Houston, Texas, May 20.-I presume there is no richer soil on earth than that formed by the annual overflow of its banks by the mighty Mississippi. That inundation has been checked, not precluded, by the artificial Levees, which, though locally advantageous, seem to me, on a broader view, mistaken. The current of the Father of Waters is, in the main, so resistless when the river is at a high stage, and is so surcharged with the richest earth, that it has only to be modified, not arrested, to induce it to commence a deposit of fertilizing sediment. Now, if its banks were so adjusted that it would at once overflow them along its whole course, from Cairo to the Balize, it could never rise six inches above them, 
and its inundations, no longer devastating, would still further enrich, and gradually though slowly elevate the adjacent region. I distrust the permanent efficacy of any artificial Levees. It is not practicable to pile both banks of a great river for a full thousand miles; yet, without piling, nothing will surely prevent the undermining of the highest and firmest Levees, so that they will crumble into the current and be swept away, causing crevasses which human power is inadequate to close till the river falls. I predict, therefore, that leveeing will fail to keep the Mississippi within its banks; and, while I do not suggest any alternative, I submit that it were better to bear existing evils than to seek their cure through agencies likely to create evils still greater.

I juclge from what $I$ have seen that the surface of most of the acres of Lonisiana accounted land, is lower than that of the adjacent rivers and bayous. Naturally, swamps and marshes abound, mainly covered by thick forests of Live Oak, Cypress, and some smaller trees, usually standing in six to twelve inches of water, and intersected by small bayous, averaging four to six feet in depth of water, the congenial home of the alligator, as they would be of the frog and the duck, if the alligator were not fond of a meat diet. The gray moss which trails from most of the trees in these swampforests is much admired by the inhabitants, and is gathered to fill mattresses. Very little has yet been done toward draining these vast morasses, because of their very slight inclination toward the Gulf, in which direction alone can water be made to flow away from them. Ultimately, they will be severally leveed or dyked, and then pumped dry by steam; but not these many years. Meantime, the relatively dry land which separates them, being two or three feet higher, has been largely improved and cultivated, though some of it has been neglected since the War. Cane and Cotton are grown on a part of the plantations; Corn quite generally ; Potatoes and what we call sweet potatoes, with corn and some cotton, by the Blacks on their petty holdings. I had been told that the Black women no longer work in the fields; but they were at work on most of the patches we passed between New Orleans and Brashear, eighty miles westward on the Atchafalaya, where we took boat for Galveston. In many places, husband, wife, and one or two children, were hoeing side by side; and, though this kind of agriculture is not very efficient, their crops generally looked well. Where their patches are easily flowed, part of each was often devoted to Rice, 
whereof the culture in this State is rapidly extending. I understand that it is considered the surest and most profitable grain-crop grown in Louisiana, while it requires no costly machinery to fit it for sale. 'The grower takes it in its rough state to the mill, where he receives 100 pounds of the cleaned or hulled grain for each 160 pounds in the hull, called "paddy." A poor man can do better at growing Rice than Cotton.

I doulbt that one-eighth of the area of Louisiana is to-day under tillage, while she grows little or no other than wild grasses of slight value. She has some millions of acres of thin, poor, sandy soil in her northern and eastern sections, usually covered with Pine, some of it of good size and quality, the rest small and worthless. Leaving this to grow timber, the residue is exceedingly fertile; yet less than half of it is arable without the aid of steam. By-and-by, bayous will be dredged, dykes or levees constructed, large inclosures pumped dry, then plowed and tilled by gigantic steam-engines; and then Louisiana' will rapidly take rank among the most productive and populous of the States composing our Union.

H. G.

\section{SUGGESTIONS TO FARMERS.}

ADDRESS BY HORACE GREELEY, OF NEW YORK, AT THE STATE AGRICULTURAL FATR.

Houston, Texas, May 23, 1871.-The civilization of our race is evinced and measured by the growth and progress of its Agriculture. The thorough savage is never a cultivator. What the earth spontaneously produces, he appropriates without gratitude and consumes without forecast. He revels in abundance one week, to be pinched by hunger the next. Only his want of an ax or his ignorance of its use precludes his felling, and thus destroying, the tree which, for generations, has fed his tribe with its nourishing, palatable fruit. He delights in gorging himself on the flesh of animals, but never feeds nor shelters them. Thus devouring and devastating, never tilling nor producing, he requires square miles to subsist scantily, precariously, his tribe, where his civilized successor will feed and clothe more persons gencrously on so many acres. After poets and dreamers have done their best to glorify him with

$$
\text { "The light that never was on sea or land," }
$$


the savage is a miserable creature, enjoying less and suffering more than the wolf or the leopard, to which a lawless, careless, predatory freedom is truly natural, and which is at home with the elements, as he never was nor can be.

The savage builds no monuments-leaves but scanty proofs that he ever existed save his bones. A hundred of his generations come and go, leaving the earth and its living vesture essentially as they found it. But let civilized man replace him for a bare lifetime, and he leaves foot-prints that centuries will not efface. Our Atlantic seaboard has hardly been known to civilized men for four generations; yet, if these were to be swept away to-morrow, and the wilderness untrodden by human foot were here to resume its ancient sway, more nemorials of these four generations would challenge attention and reward inquiry two thousand years hence than we can now discern of all the races that peopled this Atlantic islope prior to the voyages and discoveries of Columbus.

The rigors of Winter, and the experienced perils of starvation rduring its reign, gradually impel the savage to save and store the grains and fruits of the seasons of plenty to subsist him through the dearth which regularly follows: and he slowly learns to preserve and tame the animals best calculated to serve him by draft or as food. The grains which habitually grow and ripen on the fertile intervales of streams which annually overflow their banks, ultimately teach him to increase their quantity and render their reproduction more certain by cultivation. To plant the seed in the most promising localities and take the chance of its reproducing its kind ten or twenty-fold, is his first essay ; necessity impels and experience gradually teaches more methodical and efficient cultivation. The loss of cattle by cold, by storm, by hunger, at length suggests the curing of fodder for winter nse, and the provision of such shelter as the climate may seem to require. The supply of food being thus doubled and trebled, population increases correspondingly; and thus is created a necessity for a still more thorough and effective tillage of the soil. Thus pressed by want or a justified apprehension of it, Man slowly learns to deepen his culture, to fertilize lis fields, to diversify his implements and improve his methods, until the labor of one produces adequate sustenance for many, and ever-enlarging conceptions, wants, capabilities, achievements, enjoyments, expand his intellect, refine his nature, and exalt his aspirations. His increased power over Nature is the 
general measure of his progress from the lowest barbarism up to that perfect mental and moral stature which is symbolized by Copernicus, Galileo, Shakespeare, Milton, and Newton.

Modern Agriculture is an art-or rather a circle of arts-based upon Natural Science, which is a methodical exposition of Divine Law. The savage is Nature's thrall, whom she scorches, freezes, starves, drowns, as her caprice may dictate. He lives in constant dread of her frosts, her tornadoes, her lightnings. Science teaches his civilized successor to turn her wildest eccentricities to his own use and profit. Her floods and gales saw his timber and grind his grain; in time, they will chop his trees, speed his plow, and till his crops as well. Science transforms and exalts him from the slave into the master of the elements. If he does not yet harness the electric fluid to his plow, his boat, his wagon, and make it the most docile and useful of his servants, it is because he is still but little advanced from barbarism. Essentially, the lightning garnered in a summer cloud should be as much at his command and as subservient to his needs as the water that refreshes his thirsty fields and starts his hitherto lifeless wheels.

Nowhere has human stolidity been more forcibly demonstrated than in the average farmer's bygone dealings with water. This mobile, subtle fluid, which will voluntarily travel wherever you will, if you give it an inch of descent per mile, ought to have long since been absolutely and everywhere at the beck and call of every cultivator. And yet, I have stood beside a corn-field parched and withering from drouth, while a mill-stream danced and brawled right through its center, falling twenty feet in a hundred rods, yet moistening the roots of no plants but those of the two rows next its bed on either side, while three days' work of two men would have dammed and diverted its waters so that four or five acres of the corn would have been unrolled and set to growing again by their influence. Whoever travels with open eyes may note a thousand such opportunities in almost any State-a hundred or more in nearly every County.

With Grass, the facility and advantage of Irrigation are still more obvious. I visited last Summer the region of the White Momntains -Coos, the northernmost county of New-Hampshire. That district is cold, mountainous, rugged, rocky, with a strong, granitic soil, which does not lend itself easily to tillage, but which is very natural to grass. And, so numerous are the horses required for the use 
of its many Summer visitors, that Hay is always worth $\$ 20$ per ton, and, in Winters following dry Summers and Autumns like the last, considerably more. It is a country of abundant springs and rills, and dancing, laughing streams, which fall so rapidly as to make Irrigation an obvious and profitable resort. I ann quite sure that ten thousand acres of grass land in that county might be amply irrigated, by dams and reservoirs and shallow ditches, at an average cost of $\$ 20$ per acre, and with an average increase in their annual lroduct of one ton of good hay per acre, worth at least $\$ 10$ as it stands in the field ready for the scythe of the mower. Here would be fifty per cent. annual return for the investment; and its value is likely to increase rather than diminish. And yet, I doubt that there are one hundred acres of that county irrigated: and what wonder, since the farmers of the older and richer counties south of it, whose fields have been cultivated from one to two centuries, have not yet realized the thriftlessness and waste of letting rills and brooks dance idly by and through the crops that are perishing from thirst? While the rich valleys of the Connecticut and Kennebec, which have for generations been tilled by farmers exceptionably wealthy and intelligent, exhibit not an acre irrigated to every thousand left to depend for water on the caprice of the often scorching, withering skies, what can we reasonably expect of newer, ruder, poorer communities?

If Irrigation were a novelty, Conservatism might shake its head gravely, doubtingly, thereat, without exposing its emptiness of brains. But in fact the artificial application of water to secure and increasc production is older than the Plow-older than authentic History. Nature gave the example and the broadest possible hint in the valley of the lower Nile; Italy borrowed and improved upon the suggestion in the early morn of Christendom, if not earlier; and the Spaniards brought the art to this country before the Pilgrims built their huts around Plymouth Rock. How came it that lessons so striking and so palpable can have so long been defied by a people so alert and eager for profit as ours?

I believe the time is at hand when not only will streams be generally utilized to moisten adjacent fields, and thus largely increase their product, but when every thirsty, arid plain will have its bounteous well, with a wind-mill erected over it to pump its contents automatically, at little cost, into a reservoir where, after being warmed by the sun, and perhaps fertilized, they will be drawn away in 
gentle rills to irrigate acre after acre on every side. I believe that even Texas could richly afford to dig and equip a thousand such wells this summer, and many thousands in the course of the next dozen years. Every plain or intervale that slopes gently, imperceptibly, to the stream which divides or bounds it, should lave its well at the highest corner, with a spacions shallow reservoir by its side, and ditches leading thence to every point whence gravitation would carry the water gently over and through the soil of nearly or quite all its area. Even thongh that water should shrink until it utterly failed in seasons of severest drouth, the soil would still respond to the freshening influence of the moisture with which it had been charged and saturated during the fervid weeks and months required to dry up its deeper sources. Meantime, the crop would be perfected, and the drouth, when it did at last fasten on the irrigated plain, would perforce exhaust itself on the season of Nature's annual sterility and wintry repose.

In the great Future which Science and Human Energy are preparing, Artesian wells, bored to depths of a thousand to fifteen hundred feet, will be sunk on every arid plain, and near the head of every capacious valley wherein water is deficient, to enable the strong currents that flow from subjacent mountain or elevated plateau between diverse strata to rivers and seas to rise by gravitation to the surface and fruitfully overspread hundreds of acres, instead of uselessly coursing in darkness beneath. These wells, being costly, will long be comparatively rare; but the "Staked Plains" of Texas and New-Mexico, with the wide mis-named "Desert" at either foot of the Rocky Mountains, will yet be transformed into the verdurous, plenteous feeding-ground of innumerable cattle and sheep by irrigation, whereto Artesian wells will largely contribute; one of them subserving the end of many ordinary wclls, while drawing water from sources beyond the reach of any or all of them.

Agriculture, as it steadily rises from the low level of barbarism to the commanding altitude of a true civilization, becomes a more and more intellectual calling. The rude pioneer,wrestling stubbornly with the giant forest or the inhospitable marsh, may waste half his time in play or idleness; but his work, when he does work, is purely muscular, making no draft on mental power or culture. His fields are subdued and tilled, his crops produced and secured, almost wholly by dint of the strength in his good right arm. But, for his civilized, 
enlightened descendant and successor, all this is changed. Water, wind, steam, supply the needed power; his task is 'to mold and guide that power to beneficent ends. In my boyhood, the man who cut an acre of heavy grass clid therein a good day's work, which taxed his physical energies to the utmost and sent him weary and exhausted to bed, to rise stiff and sore for the morrow's duties; now, any intelligent, resolute girl of fifteen, guiding a span of horses, may cut five acres of just such grass before noon, cut it better than the best mower ever did, and alight from her seat on the mowing-machine untired and eager for a pic-nic or frolic after dimer. Steam saws wood into fuel for the kitchen fire-place and the parlor stove; cuts stalks and straw into half-inch pieces and then cooks them into a pulpy mass ; slices roots ; churns cream into butter withont supervision; and is just harnessing itself to the plow, resolved to pulverize the soil more rapidly, more cheaply, to a greater depth, to a more equal and perfect comminution, than it has ever been possible to attain by the force of animal power. Manifestly, we stand but on the threshold of the new age whereof Steam is at once the harbinger and the impulse: but emough has been developed to assure us that more and better is at hand.

Nor should we doubt that Steam itself is the forerunner of agencies still more potent and more cheaply efficacious. Mighty as have been its achievements, they only serve to render more obvious and lamentable its limitations. Of the power actually generated by the raporization of water, I cannot say how great is the share utilized by an ordinary steam-engine, but I believe the estimates of scientists all range below twenty per cent. Then the enornous weight of boiler, fuel, and water, that must be transported with every form of locomotive, absorts neariy half the power not squandered by imperfect devices for directing and applying it. Mighty as Steam assuredly is, it is not only a blind giant, but we are deplorably blind with regard to its economy and alaptation.

And why should Steam, even in its best estate, be final? Intelligence has already spurned its trammels; Thought has far outstripped it in the invention and operation of the Magnetic Telegraph; why should the wondrous power we have evoked in Electricity be limited to the transmission of ideas? Why may it not be employed to impel material substances as well? True, we have not yet learned how to transmit the power unquestionably generated by Electricity; but our average ignorance and incapacity, result- 
ing in obstruction and defeat, are constantly overstepled and transfigured by the men of genius and of prescience whom God benignantiy sends to lead us on from achievement to achievenent, from triumph to triumph. To be conscious of a need or a deficiency, is to be far on the way whereby we shall at last overcome it. Steam, as a productive force, an industrial factor, is barely a century old; Electricity was harnessed to a wire and made a post-boy hardly thirty years ago. I do not believe this all, nor even the best, that this all-pervading, irresistible power is destined to do for us. I believe that plants will yet be grown by its aid with a celerity never yet attained; that heat will be profitably produced and diffused by its agency; and that power will be generated from electric batteries, of old or new device, which will supplement, if not in time supersecle, all other mechanical forces, liberating Man nlmost wholly from obstruction and defeat by material obstacles, and rendering Productive Industry a matter of application and oversight, rarely or never tixing human sinews to achieve a result which invokes the employment of material force.

If I do not speak here of what, in my section, as in Europe, is the basis of all thorough culture-I refer to Under-draining-it is not because I deem it inapplicable to your State, but simply that the time when it can be expected to command general attention here has not yet arrived. You do not need to warm your soil, lengthen your season of verdure, or hasten the growth and maturing of your crops, as we do ; and there are but few square miles of your State on which a net-work of under-drains three feet in average depth and but three rods apart, would not cost more than it would be worth. And yet, I have no doubt that many gardens, nurseries, \&c., in this State ought to be thus drained, and would be to profit, if only to relieve them of an excessive moisture in Spring and early Summer, remaining stagnant in and souring the soil. By-and-by, yon will begin to under-drain grain-fields and meadows as we do; but that topic can wait. The draining of bogs and marshes, by widening, deepening, and straightening, the chaunels wherein water now flows from them-often making new ones in part, if not wholly -proffers more obvious and instant advantages. The lands waiting to be thus reclaimed are nearly always exceptionally fertile; they rarely present other obstacles to cultivation than water; while their proper drainage must contribute signally to the healthfulness of the surrounding country. No State which embosoms extensive swamps 
or bogs should hesitate to have them surveyed by competent engineers and the best means of drying them ascertained and reported. Knowledge will almost inevitably lead to practical, decisive action with regard to these nurseries of fever, these magazines of disease and death.

Bear with a few suggestions upon a standing topic of debate among Sonthern cultivators.

I am not young, as you see; yet I cannot remember a time when the South did not affirm and deplore an excessive addiction of her people to Cotton. That eminent scholar and statesman, Hugh S. Legaré, alluded to it as a venerable grievance, thirty-orld years ago. Before as well as since, every one remonstrated with every one against the fatuity which impelled Southrons to plant so much Cotton; exhorted all to retrench and reform; and then slid away to plant a few more acres than ever before. For generations, it was rëiterated as an axiom that Cotton culture depended on Slavery; yet Slavery is dead, and we produced nearly One Million tons of Cotton in 1870-more than in any former year, with the exceptions of 1859 and 1860. Yet, in this year of grace 1871, we have the old cry from millions of throats-"Plant less Cotton!"-and I presume with the old result. The army-worm, the boll-worm, may diminish the Cotton-crop; expostulation, I judge, will not. I know no more striking illustration of what St. Paul terms " the foolishness of preaching " than this incessant yet fruitless clamor against growing so much Cotton.

Doubtless, the remonstrants are right, as remonstrants are apt to be. But, after two generations of incessant deprecation, the passion for cotton-planting seems as intense and pervading as ever. The owner of a thousand arable acres, after hearing all that is to be said against it, plants almost exclusively Cotton. The poorest negro, who owns or rents a dozen acres, puts in his field of Cotton, and takes his chance for bread. He has endured less preaching on the subject than his old master; but, had he been lectured from infancy on the madness of cotton-planting, he would have planted all the same.

And this for a most obvious reason. Cotton is Money, and Money is Power. Cotton is of such moderate bulk in proportion to its value that it bears transportation far better than Wheat, or Corn, or Fruit, or Vegetables. It endures tropic suns and aretic frosts without injury; it neither molds, nor rots, nor rusts, nor 
putrefies. He who has Cotton to sell does not quake at the footstejs of the tax-gatherer, and ean generally look the sheriff square in the face.

Admitting that the South has grown, and still grows, too much Cotton-(and I judge that three millions of bales grown in 1870 would have netted her as large a sum as the four millions she actually did grow) - I see no way to counteract this tendeney but by introducing new branches of industry whereof the product will also command money. In vain do you exhort the average planter to grow more Coru and make more Pork: he is often in debt, and chooses to produce what will surely sell for the money he sorely needs. He is sure Cotton will do this; he is not so sure as to Corn or Pork. But plant one hundred Cotton and as many Woolen Faetories on the soil of your State, making a steady cash nuarket here for Wool and Neat, for Grain and Vegetables, as well as Cotton, and now your Agriculture will naturally and certainly divide its forees and diversify its jroducts. Farmers will grow diverse crops, if they know that a sure eash market is at hand. A denser population, a greater variety and range of employments, these are pressing wants of the entire Sonth. Every wheel set to turning on a Southern water-fall, every manufactory of Eilge-Tools or Farm Inplements, started in any of your cities or villages, is certain profitably to divert labor from your Cotton-fields, as naked preaching never will. There is hardly an acre of Southern land which would not be doubled in value if Southern farms were mainly eultivated with Southern-made implements, Sonthern backs elothed in Southernwoven fabrics, and Southern dwellings filled with Southern-made furniture and wares. And, now that Slavery has gone out, it is high time that the useful arts were steadily and rapilly coming in.

Am I inculcating what would injure my own section? Not at all. The more you do for yourselves, the more you will require from abroad. The State of Arkansas has more inlabitants than the City of Boston; yet the latter, while the focus of an immense interchange and large eonsumption of domestic products, buys and consumes far more of the productions of foreign lands. Our purchases are limited, not by our needs, but by our means. A thousand times it has been predieted that we should destroy our Foreign Commerce by proteeting Home Industry, and a thousand times this has been proved a fallacy by inereased imports under high duties. 
If Texas were expending four times as much as she is, per annum, in the purchase of home-made wares and fabrics, she wonld buy far more from abroad than she now does. If she had a dozen ax-factories in full operation, she inight import fewer axes than now, but her imports of Steel, Iron, and a hundred other articles, would be swelled beyond computation.

I hold the naturalization of new and the extension of existing Manufactures among the most urgent wants of this State, as of nearly every young community. Hence, I hold-not that you onght to pay a high price for a poor article because it is home-made - not that you should forego the gratification of a legitimate want because the article it contemplates is not of Texas growth or fabrication-but that each of you should give an intelligent preference, other things being equal, to whatever is made on your own soilshould buy your harness, or saddle, or pail, or broom, or plow, or ax, of your neighbor's make, in preference to one brought from abroad; shonld take and pay for some first-rate Texas journal before looking abroad for a better. Having thus done your duty by the community whereof you are a part, if you are able and willing to take a second journal, I might possibly aid you in finding a good one.

Is Agriculture a repulsive pursuit? That what has been called Farming has repelled many of the youth of our day, I perceive; and I glory in the fact. An American boy, who has received a fair common-school education and has an active, inquiring mind, does not willingly consent merely to drive oxen and hold plow forever. He will do these with alacrity, if they come in his way; he will not accept them as the be-all and the end-all of his career. He will not sit down in a rude, slovenly, naked home, devoid of flowers, and trees, and books, and periodicals, and intelligent, inspiring, refining conversation, and there plod through a life of drudgery as hopeless and cheerless as any mule's. He has needs, and hopes, and aspirations, which this life does not and onght not to satisfy. This might have served his progenitor in the Ninth Century; but this is the Nineteenth, and the young American knows it. He needs to feel the intellectual life of the age flowing freely into and through him-needs to feel that, though the City and the Railroad are ont of sight, the latter is daily bringing within his reach all that is noblest and best in the achievements and attractions of the former. He may not listen to Sumner or Thurman in the Senate; 
to Ward Beecher or Tyng in the pulpit; but the press multiplies their best thoughts and most forcible expressions at the rate of ten to twenty thousand copies per hour; and its issues are within the reach of every industrious family. Any American farmer, who has two hands and knows how to use them, may, at fifty years of age, have a better library than King Solomon ever dreamed of, though he declared that "of making of many books there is no end;" any intelligent farmer's son may have a better knowledge of Nature and her laws when twenty years old than Aristotle or Pliny ever attained. The Steam Engine, the Electric Telegraph, and the Power Press, have brought knowledge nearer to the humblest cabin than it was, ten centuries since, to the stateliest mansion; let the cabin be careful not to disparage or repel it. To arrest the rush of our youth to the cities, we have only to diffuse what is best of the cities throughout the country; and this the latest trinmphs of civilization enable us easily to do. A home irradiated by the best thoughts of the sages and heroes of all time, even though these be eompressed within a few rusty volumes, cheered by the frequent arrival of two or three choice periodicals, and surrounded by such floral evidences of taste and refinement as are within the reach of the poorest owner of the soil he tills, will not be spurned as a prison by any youth not thoroughly corrupted and depraved.

But thousands of farmers are more intent on leaving money and lands to their children than on informing and enriching their minds. They starve their souls in order to pamper their bodies. They grudge their sons that which would make them truly wise, in order to provide them with what can at best but make them rich in corn and cattle, while poor in manly purpose and generous ideas.

-It may seem presumptions in me to speak to you of the preservation and diffusion of Trees in a State so new as yours, and of whose alternations of hill and valley, forest and prairie, you know so much and I so little. But there are laws everywhere potent, needs everywhere felt, and errors very generally committed; and of these last the most pervading is the reckless extermination of Trees. It is not peculiar to this continent; for France and Spain, Italy and Portugal, have for the most part been denuded of forests, and suffer for it not only in the scarcity of Timber and Fuel, but in the severity and duration of their drouths, the fierceness and devastations of their gales, the violence and aggravation of their floods. All of them have timber on their rugged, sterile moun- 
tains, where it is scarcely accessible, and where it is least available to their denser and more active communities. But if one-tenth of the surface of each arable square mile were now covered with stately and serviceable forest-trees, those countries would be better fitted to maintain a large population, and their inhabitants would be more thrifty, eflicient, and comfortable, than they are. My own section of this continent has destroyed trees too eagerly, recklessly, and planted them too tardily, too sparingly. My county, of Westchester (New York), began to be inhabited by our race fully two hundred and fifty years ago; it has been divided into farms from one to two centuries, and its people are not behind other's in sagacity and intelligence; they have still much land covered with mainly young timber; yet there are not less than five thousand acres in that county to-day exposing rocks thinly and partially covered with soil which ought never to have been stripped bare of trees. Cut off the timber, if you will, though it is better to thin ont than to sweep away a forest where the land is not needed for tillage, and have trees of all ages and sizes growing on each acre devoted to forest. If those five thousand acres were reclad in their primitive vesture, all the springs and streams of the county would be more copious, more equable, more constant, than they are, and the soil of the subjacent fields and meadows would endure drouth and retain moisture as they never can while hill-side and rocky ridge are exposed to sweep of wind and glare of sun.

In this new, bounteous, sunny land, where the need of fuel is so much less than with us, you are exposed to the miscalculation made by my ancestor's two to four generations back, when, seeing seveneighths of New-England covered by stately, luxuriant trees, they said, "There will always be timber enough. Let us cut and slash, and clear all the land we can; others will save wood enough though we destroy all we have;" but their ehildren have lived to deplore their error. Fifty-five years ago, great pines were cut from hills now included in the city of Burlington, Termont, sawed into boards, and these rafted down Lake Champlain and the Sorel to the St. Lawrence, and so shipped to Europe, not paying fifty cents per day for the labor, calling the worth of the timber nothing. Barcly thirty years later, when Vermont began to construct her railroads, she had to draw the brilge-timber fiom Canada, paying for it many times what her own disparaged pines brought when they were so recklessly swept iway. The world is full of experiences as instructive as this. 
It is not too soon to begin to plant forests in the more naked and arid portions of Texas; it is high time that you were regarding good timber as property, and saving it with scrupulous care and foresight. Extensive sections of your State will need it before they can grow it, aside from those loealities which need it alrealy; and your Society can do her no better service than to impress on all owners of the soil, whether in village or rural district, the duty and profit of an annual and persistent planting of choice and serviceable Trees.

But-not to trespass too far on your patience-let me close with a few maxims, applicable to cultivation in every clime and under all circumstances, whether among populations dense as that of China or sparse as that of British America.

I. Only Good Farming pays. He who sows or plants without reasonable assurance of good crops annually, might better earn wages of some capable neighbor than work for so poor a paymaster as he is certain 'to prove himself.

II. The good farmer is proved such by the steady appreciation of his crops. Any one may reap an ample harvest from a fertile virgin soil; the good farmer alone grows good crops at first, and better and better ever afterward.

III. It is far easier to maintain the productive capacity of a far'm than to restore it. To exhaust its fecundity, and then attempt its restoration by buying costly commercial fertilizers, is wasteful and irrational.

IV. The good farmer sells mainly such products as are least exhaustive. Necessity may constrain him, for the first year or two, to sell Grain, or even Hay; but he will soon send off his surplus mainly in the form of Cotton, or Wool, or Meat, or Butter and Cheese, or something else that returns to the soil nearly all that is taken from it. A bank account daily drawn upon, while nothing is deposited to its credit, must soon respond "No funds :" so with a farm similarly treated.

V. Rotation is at least negative Fertilization. It may not positively enrich a farm; it will at least retard and postpone its impoverishment. He who grows Wheat after Wheat, Corn after Corn, for twenty years, will need to emigrate before that term is fulfilled. The same farm cannot support (nor endure) him longer than that. All our great Wheat-growing sections of fifty years ago are Wheatgrowing no longer; while England grows larger crops thereof on 
the very fields that fed the armies of Saxon Harold and William the Conqueror. Rotation has preserved these, as the lack of it ruined those.

VI. Wisdom is never dear, provided the article be genuine. I have known tarmers who toiled constantly from daybreak to dark, yet died poor, because, through ignorance, they wrought of disadvantage. If every farmer would devote two hours of each day to reading and reflection, there would be fewer failures in farming than there are.

VII. The best investment a farmer can make for his children is that which surrounds their youth with the rational delights of a beusteous, attractive home. The dwelling may be small and rude, yet a few flowers will embellish, as choice fruit-trees will emrich and gladden it; while grass and shade are within the reach of the humblest. Hardly any labor done on a farm is so profitable as that which makes the wife and children fond and proud of their home.

VIII. A good, practical Education, including a good trade, is a better outfit for a youth than a grand estate with the drawback of an empty mind. Many parents have slaved and pinched to leave their. children rich, when half the sum thus lavished would have profited them far more had it been devoted to the cultivation of their minds, the enlargement of their capacity to think, observe, and work. The one structure that no neighborhood can aftord to do without is the school-house.

IX. A small library of well-selected books in his home has saved many a youth from wandering into the buleful ways of the Prodigal Son. Where paternal strictnes: and severity would have bred nothing but dislike and a fixed resolve to abscond at the first opportunity, good books and pleasant surroundings have weaned many a youth from his first wild impulse to go to sea or cross the continent, and made him a docile, contented, obedient, happy lingerer by the parental fire-side. In a family, however rich or poor, no other good is so cheap or so precious as thoughtful, watchful love.

$\mathrm{X}$. Most men are born poor; but no man, who has average capacities and tolerable luck, need remain so. And the farmer's calling, though proffering no sudden leaps, no ready short-cuts to opulence, is the surest of all ways from poverty and want to confort and independence. Other men must climb; the temperate, frugal, diligent, provident farmer may grow into competence and every external accessory to happiness. Each year of his devotion to his home- 
stead may find it more valuable, more attractive than the last, and leave it better still.

Farmers of Texas! I bring you mainly old and homely truths. No single suggestion of this Address can be new to all of you; most of them, I presume, will be familiar to the inajority. There are discoveries in Natural Science and improvements in Mechanics which conduce to the efficiency of Agriculture ; but the principles which underlie this first of arts are old as Agriculture itself. Greek and Roman sages made observations so acute and practical that the farmers of to-day may ponder them with profit, while modern literature is padded with essays on farming not worth the paper they have spoiled. And yet, the generation whereof I am part has witnessed great strides in your vocation, while the generation preparing to take our places will doubtless witness still greater. I bid you hold fast to the good, with minds receptive of and eager for the better, and rejoice in your knowledge that there is no nobler pursuit and no more inviting soil than those which you proudly call yór own.

\section{TEXAS...THE STATE MATERIALLY CONSIDERED.}

[EDITORIAL CORRESPONDENCE OF THE TRIBUNE.]

Houston, Texas, May 25.-- "How do you like Texas?" I have been many times asked during the week I have been in the Stateasked even before I was at all qualified to give an answer of any value. Now that I have traveled some hundreds of miles, mainly in the valleys of the Trinity and the Brassos, I can speak somewhat more to my own satisfaction. Still, it should be considered that I have as yet seen only the south-eastern quarter of Texas, and but a small proportion of that. Of course, I knew long since that Texas has a warm though variable climate, and a soil generally, though not uniformly, fertile. Few who read considerably can need to be told so much. Let me endeavor to indicate the points on which observation has modified my former inipressions.

I. Texas seems to be better timbered than any other prairie State with which $I$ am acquainted. I do not mean that the timber is exceptionally good, for it is not. Eastern Kansas, with her Hickory groves and the stately, luxuriant forests that cover the intervales 
("bottoms") of her rivers, is decidedly ahead of her in this respect. But the prairies of Eastern Texas, though often large, are interrupted, chequered, diversified, by clumps or groves of timber, as I never saw any other. Wherever water finds or makes a course, no matter how shallow or how generally dry, there trees spring up and struggle resolutely for existence. And, since these prairies and glades have been fed down by innumerable cattle, the ammual prairie-fires, if not prevented, are so enfeebled, by the relative seantiness of their aliment, that they no longer charge upon and drive back the timber as they formerly dicl. It is plain that the forests are steadily extending their boundaries on every sicle, while every tree cut out of them is replaced by half a dozen young ones. I judge that the increase of timber throughout the region I have traversed has been very great during the last ten years, and that it will continue for the next twenty, in spite of the rapid increase of population.

As to quality, this timber is not what I conld wish it. Oaks, of almost every known variety, with two or three species of Pine, are most abundant; while Cottonwood, White Ash, Pecan, Elm, Gum, de., garland the rivers and bayous. The Live Oak is quite common, and is a good timber-tree; the long-leaf Pine is of tolerable quality, though not equal to our White Pine. But most of the Oak is "brash," as the woodmen say-that is, it lacks toughness and elasticity. Much of it is low and scrubby, but the young trees, growing thickly, promise to be tall and comparatively limbless. I hope their timber will prove more elastic than that it replaces. I would gladly hear that Hickory, Locust, Larch, and other desirable species, are extensively planted ere long. As yet, more sawed Pine is imported (especially for bridge-building) than I wish was needed.

II. As to the Soil, I have seen few acres that would not yield good crops to good cultivation; but this is expected of a prairie country. Some of the pine-covered lands, especially near the Gulf, seem but moderately fertile; a part of the upland "Oak openings" only a little better. On the other hand, the river bottoms, especially those of the Brassos, are very fertile, as annually overflowed intervales are apt to be. Here, however, the inundations are frequent and of enormous extent, so that I juclge the intervales of the Trinity, Brassos, Colorado, dre, deeper and richer than those of the Connecticut, Hudson, Delaware, Susquehauna, or Potomac, ever were or could be. I never saw better soil than the Brassos bottoms.

I was more surprised, however, by the remarkable fertility of the 
rolling prairies, especially those of Washington County, on either side of Brenham, its capital. These have been twenty to thirty years planted to Corn or Cotton, never manured, and cultivated so shallowly that every rain sweeps off thousands of tons of their soil to be borne into the Gulf by the Brassos or squandered upon its intervales. Yet these prairies still sustain and mature bounteous harvests; and no wonder, since their black mold ranges from two to five feet in depth. Mellow, dry, breezy, healthful, I do not see how these lands could be made more inviting.

The level prairies are of good quality, though not equal in the average to those just spoken of. They may average a foot of dark mold, generally overlying clay. They are mainly left in a state of nature, and devoted to the rearing of cattle, which are sold at three or four year's old for $\$ 10$ to $\$ 20$ per head to drovers or packers. Tens of thousands in good condition have been slanghtered for their hides and tallow - the flesh, after yielding all its tallow, being fecl to swine. This, I' trust, is ended; it certainly will be when the first railroad shall have connected the valley of the lower Colorado with that of the Missouri or the Olio. As yet, the State is full of cattle, and will be for a few years longer; but they must ultimately give place to tillage. Whenever lands devoid of stump or stone, equal to those of the Connecticnt valley, and within fom days by rail of New York, shall be worth $\$ 5$ per acre, these prairies will be gradually inclosed, broken up by the Steam Plow, surfacc-drained by gigantic machines, and cultivated for Corn, Cotton, Wheat, or some choice Grass; and then Cattle will gradually disappear, or be reared in some more civilized fashion. At present, they simply hold the ground till Cultivation shall be ready to claim it.

IIT. Whether it be a recommendation or not, I judge that it has required less effort to live in Texas than in any other State of the Union. The common saying, "It costs no more to rear a cow here than a hen at the North," is literally true. The cow was never fed, never sheltered, no matter how cold or stormy the weather; and you might have ten thousand head of cattle ranging the prairies and openings without owning an acre of land on earth. Hany a man has thus grown rich without effort and almost without thought.

Rich, but to little present purpose. His home was a rude cabin, with little or no glass in its windows, and nothing but dirt on its floors. His children grew up unschooled and rude-mannered. His 
wife was slatternly, deprived of society, and rendered unhappy by memories of better times and more congenial associations. Man lives as a herdsman mainly on horseback, in the open air, often meeting acquaintances or strangers; Woman, being confined to her small, rough cabin, found therein no solace, no comfort, but in her children. The partnership was not an equal one; there was no similarity in its conditions. There are proud and happy wives in Texas as elsewhere, but the rancher's life has not tended to make them so. I am glad that I can see to the end of it. And I trust that the ranchemen's wives are even gladder than $I$ am.

While Slavery iasted in Texas, any decided change was hardly possible. The tillers of her soil were slaves. White men almost uniformly refused to " make niggers of themselves" by plowing and hoeing; but they did not hesitate to mount a horse and gallop after" a herd of Cattle. Boys early learned to lasso a steer or colt; they liked the herdsman's life, with its excitements and adventures; it was the next thing to a buffalo-hunt. Land had no value; products, unless near navigable water, next to none. Many a man has been unable to sell his Corn at 25 cents per bushel in one County, when no better Corn was wanted at six times that price in another; impassable streams and unfathomable roads separating them. So the owner of five thousand cows was often for weeks without flour bread, and very rarely had either Cheese, Butter, or Milk; "hog and hominy" were his staples for diet; Fruit he seldom tasted; Tobacco and Whisky were his only luxuries.

So much for the Past. I will speak of the Future in my next.

H. G.

\section{TEXAS...THE FUTURE OF THE STATE...ITS RAILROADS.}

[EDITORIAL CORRESPONDENCE OF TIL THIBUNE.]

Cocurrus, Colorado Co., Texas, May 26.-Before I dilate on the bright future now opening before this State, let me indicate some of the drawbacks which have hitherto retarded her material and still more her intellectual and moral progress.

Bad water is quite often the accompaniment of very good land; and South.Eastern Texas has little that is good. I have now traveled over nearly every completed mile of her railroads without having 
been offered one glass of water from spring or well. Rain-water is very generally drank; nearly every tolerable dwelling being provided with a tank or reservoir for keeping it, oftener underground. As very many lack even this, the excuse for drinking bad coffee, or worse whisky, is here stronger than almost anywhere else. That springs are very rare, while well-water is uniformly undrinkable, is certain ; but why each city and considerable village has not tried to obtain better, by sinking to a depth of two or three hundred feet (not expecting the fluid to rise to the surface and flow over, on the Artesian plan, but drawing it up by wind or other power), I do not understand. The muddy product of the rivers, creeks, bayous, and sloughs, which the cattle must imbike per furce, camnot but be prejudicial to their health and thrift; to say nothing of the dry seasons, when even this detestable stuff can harlly be obtained. The suffering of animals from thirst, and from the villainous witch-broth wherewith they must quench it, must work them serious harm. If I were a herdsman here, I would have better water for my stock, or I would sink at least three hundred feet in quest of it.

$B$ ad roads and other impediments to inter-communication have sadly crippled Texas, and still cripple her. Her crops, as a general rule, have cost the grower more after than before harvest. 'Though oxen and horses have long been abundant and cheap, the wheat-growers up North could reach no market with their product unless at ruinous cost, while the lower counties were importing Flour at the rate of three thousand barrels per day. A State whose chief products are Grass and Cattle, has imported both Hay and Milk; her herdsmen, as a general rule, never see either. A purely agricultural State that buys most of her bread, a splendid soil for Corn on a good part of which Corn is dearer to-day than in NewYork City, a capital State for growing Swine at no cost, yet which las bought three-fourths of the Hams universally consumed by her people-such are among the causes which have kept her people poor in spite of the remarkable fertility of her soil. Her rivers, creeks, and bayous, rarely bridged, are subject to great and sudden floods, whereby teamsters are often imprisoned for days between two creeks which in dry seasons are waterless, and halted by a river for weeks. But for Railroads, Texas is doomed by nature to stagnation, impotence, and barbarisn.

As yet, she has barely begun to be penetrated by railroads. A line north by west from Galveston to Houston (50 miles), and 
thence by Hempstead, Navasota, Bryan, Hearne, \&c., to Groesbeck, in Limestone Comnty, soon to be extended to Corsicana, in Navarro County (say 250 miles from Galveston), with a branch from Hempstead westward across the Brassos through Washington County to Giddings, 55 miles, soon to be extended 50 miles further to Austin, the State Capital, with another from Harrisburg, 6 miles below Houston, through Fort Bend and Colorado Counties, across both the Brassos and Colorado to this point ( 84 miles) : such are about all the pieces of railroad now in operation in the State. The piece from Shreveport, Louisiana, westward through Harison and Snith Counties to Hallsville (56 miles), is rather a suggestion than a practical road. And these are about all that are in operation today. The work of providing this people with necessary railway communication is barely well begun.

But that is half the battle. At last, nearly every line seems to be in the hands of solvent, capable, upright men, who are backed by ample caprital, and is pushed with vigor and clear-sighted resolution. The Texas Central is going right on north by west to meet one of the Missouri-Kansas roads at the north line of the State, near Gainesville or Sherman. A new road ("The Great Northeru"), well backed by Northern capital, pushes directly north from Houston, crossing the Southern Pacific near Tyler, strikes the Red River near Fort Towson, and commects with the Missomi, Kansas and Texas from Kansas near that point. The "Chattanooga and Mobile" is now pushing due westward through Louisiana, and expects to reach Houston before this time next year. These, with the Southern Pacific, now certain to be vigoronsly prosecuted, will give Texas not less than 1,000 miles of completed railroad within a year, and 1,500 within two years.

But the most important and effective single line of railroad in the State is "The International," which is to connect at Fulton, Arkansas, on her north-eastern border, with one from Cairo, 111., and thus with Chicago and New York, running diagonally through Texas from north-east to sonth-west, crossing the Southern Pacific and "The Great Norther' " near Tyler, the "Texas Central " at Heame, and thence pushing straight for Austin, the cajital, and hence to San Antonio, and so to the Rio Grande not far from Larerio. This road, though begm last November at Hearne, where it crosses the "Texas Central," and impered by the necessity of importing Corn at a cost of $\$ 2.10$ per bushel and Hay at $\$ 85$ per 
tun for its oxen and mules, has been pushed right vigorously in either direction, and will have crossed both the Brassos and Colorado, and reached Austin on the one hand, the Trinity on the other, by next May. Two years hence, it will have been completed from Fulton to San Antonio (400 miles), and will then have bronght the heart of this State within four days' travel of the Commercial Emporium, where it will be known as one of the most judicious and successful railway enterprises ever planned. It will carry more Beef Cattle than any road on the globe, and it will bring into Texas more immigrants than railroad ever carried into any State till now.

I close with a single instance of the spirit in which our Northern railroad-builders are met by the people of Texas. The Legislature having granted a liberal subsidy in State Bonds to the Southern Pacific Road, Gov. Davis felt constrained to veto the bill. The Legislature thereupon repassed it by a vote of seven or eight to one in either House; and the Democratic vote in the affirmative was, like the Republican, all but unanimous. And, while no man questions the purity of the Governor's motives, I have heard no dissent from the satisfaction with which the triumph of the measure is received.

-I hope to leave Texas on my homeward way very soon, having been dissuaded by heavy and extensive rains from my purpose of reaching Austin and perhaps San Antonio on the one hand, or'Tyler, Marshall, and Shreveport, on the other. The time does not serve. for stage-rides or other travel oft the line of operated Railroads.

H. G.

TEXAS AS A LAND OF PROMISE.

[EDITORIAL CORRESPONDENCE OF THE TRIBUNE.]

Galveston, Texas, May 27.-Texas is as large as France, with a more genial climate and far richer soil. She has to-day less than One Million inhabitants, while France (as reduced by the late war) has more than Thirty-six Millions. She has more and better Timber, and more Cattle and Horses than France; why should not her fortieth part of France's population be rapidly increased to a twentieth, a tenth, and, before the close of this century, to a fifth or fourth ? 
Why should not this State be the home of Ten Millions of the human family early in the next century?

Before deciding to say a word in favor of Texas as a home for those as yet strangers to her, I made inquiry and satisfied myself that her wild lands are not merely cheap to-day, but certain long to remain so. They are held in tracts of a thonsand to many thousands of acres, by men of limited means, who bought them for a song, or obtained them without price by Mexican concession, and who have held them to this day partly because wild lands paid no taxes, and partly becanse they could find no purchasers: every one who either had property or aspired to have being already gorged with wild land. Now all is changed. Slavery being dead, lands are in request and have a value, which railroads are rapidly doubling and quadrupling. Taxes are ligh and rising; Common Schools and State loans to Railroads are certain to enhance them; so that moneyless holders of unproductive tracts must sell or be sold out by the sheriff and tax-collector. I am sure that at least One Hundred Millions of fertile acres are to-day owned by men who must sell them within the next five years. And this necessity is sure to keep down prices. Let me, then, give some idea of their range.

I traversed yesterday the railroad which runs westward from Harrisburg near Houston, through Harris, Fort Bend, and Colorado Counties, by Richmond to Columbus, 83 miles. Most of this ronte lies through a rich, level prairie, covered with Horses and Cattle; but Timber is always in sight on one side or on both, and we pass through the generally forest-covered intervales of the Brassos and Colorado, with those of Oyster Creek, San Bernard, and Caney. This is one of the earliest settled portions of Texas, and its population has largely increased since the war. I was authorized by Mr. Wm. Brady of Houston to offer a league of it (4,400 acres), including a sufficiency of timber and water, for $\$ 1$ per acre; but, if that should not meet the views of pioneers, he would survey it into farms, and give alternate tracts of 100 acres to industrious, sober, thrifty pioneers who would settle upon and convert them into productive homesteads. And I have been assured by others that a colony of two or three hundred Northern farmers and mechanics could obtain lands for settlement on like terms in almost any part of the State.

Do not jump at the mistaken conclusion that the landholders of Texas are exceptionally philanthropic and generous. They make no pretensions to this character. They want to make their lands 
valuable and marketable; to which end, they will sometimes give away a part to enhance the value of the remainder. Only a few will do this; but almost any one will sell a part very cheap in order to obtain a price for the rest. And they are quite aware that a Yankee or German colony raises the value of the lands all around it.

The Railroads are in like circumstances. Some of them have land-grants ; all want the population and production along their lines rapidly increased. Their interest leads them to invite settlement and encourage the transfer of lands from non-residents to cultivators. Hence, while lands near railroad junctions and other locations of predicted cities are held for higher rates, I judge that half the soil of Texas is this day in market at prices ranging from 50 cents to $\$ 2$ per acre, and that $\$ 1$ per acre in cash wonld buy the greater portion of it. And, while a rapid rise along some of the railroad lines is inevitable, I judge that $\$ 2$ per acre will buy good wild land in this State for at least ten years to come.

The least favorably situated of this vacant land is more eligibly located to-day than the best was twenty years ago. Ruailroads are bringing markets and comforts to every man's door. Milk sells for $\$ 1$ per gallon in this city; there is not a quart of it to every thousand cows throughout the State; and you whiten your tea or coffee with the condensed article from New York or you don't whiten it at all, even at petty hamlets in the far interior, where a likely cow and calf will bring not more than $\$ 10$.

As yet, the Mineral wealth of this State sleeps undisturbed and useless. She has Iron enough to divide the earth by railroads into squares ten miles across; but no tun of it was ever smelted. She has at least five thousand square miles of Coal (probably much more); but no tun of it was ever dug for sale. She has Gypsum enough to plaster the continent annually for a century; but it lies inert and valueless-a waste of earth-covered stone. She has more land good for Wheat than Minnesota, yet imports nearly all her Flour; she has millions of acres of excellent Timber, yet builds mainly of pine from Louisiana and Florida; she sends to the Ohio for her Hams and to New York for her Butter, and would import Berries and Fruits if her people had not learned, while they were unattainable, to do without them. If ten thousand Northern farmers would settle just below Houston, and devote themselves to supplying that city and this with fresh Milk, Butter, Strawberries, 
Raspberries, Peaches, Grapes, \&c., they might charge double prices, and get rich faster than so many cultivators ever did before. They would have to make their own Ice, but that is not diffieult; they might have to teach the Texas Central how to run a milk-train fifty miles; but that need not exhaust their energies. Their pastureland, fenced, might eost them $\$ 10$ per acre just around a depot and a junction; their eows might be picked at $\$ 15$ per head; and they would soon sell Hay enough at 200 per cent. profit to defray the cost of feeding and shedding their stock. This is but one of a hundred equally promising enterprises now impatiently awaiting the right men to direct them. Who will send them along?

H. G.

\section{GLEANINGS FROM TEXAS.}

[EDITORIAL CORRESPONDENCE OF THE TRIBUNE.]

New Orlears, La., May 29.-Texas is a great State geographically, with immense natural resourees and gigantic possibilities; but she has not yet justified her early promise. Her wealth in soil and cattle, with the ease wherewith an abundance of food may be secured from these with little labor, has blinded her people to many shortcomings which shoukl not have endured or been endured so long. Her habitations, as a whole, are fur smaller, ruder, and less comfortable, than they might and should be. She onglit to pay for ten milliou panes of glass, and hire ten thousand glaziers to set them direetly. She is in urgent need of twenty thousand more school-teachers and fifty thousand instructed cooks. It is a grief to see beef that might be broiled into tender and juicy steaks fried or stewed into such repulsive, indigestible messes as I have encountered at all but her two best hotels. It is a crying shame for a region where the Peach, the Grape, the Pear, the Strawberry, \&c., grow so luxuriantly and bear so bounteously, to be living almost entirely on Meat, Bread, and Coffee, even if these articles were what they should be, and in Texas are not. In Labrador or Alaska, such a "hog and hominy" diet would be faulty; under this fervid sun, it is atrocions. No family which has been five years or over in Texas has any right to live so badly.

I judge that there are, at the outside, fifty acres of cultivated Berries of all kinds in the State, perhaps as many of Grapes, and 
possibly one Peach-tree to each family, though I consider that a high estimate. At all events, not one family in every ten has either fruit-tree, grape-vine, or strawberry-bed, down to this hour; and fruit makes no part of the average meal. Yet the profusion of wild grapes (Mustang) in the Brassos bottoms, covering nearly every tree for miles after miles, argues that choice Grapes would grow here if any one would only plant them; while I know that Peaches and Strawberries are hardly anywhere more luxmiant or prolific. Almost every one owns land; those who do not, easily might; but the great majority seem content to live as the pioneers of Texas had to, on coarse, gross food alone, when they might have Fruits, Milk, dc., by moderate exertion. The girls working in Lowell factories wonld strike the first day that they were fed like the family of a Texas planter who owns five thousand acres of land and a large stock of cattle.

I speak of these things at the risk of giving offense, because they ought to be discuissed till corrected. The Texas pioneer, living a hundred miles from anywhere, with a neighbor to each ten miles square, no roads and no bridges, had to fare as he could. That is no reason for cherishing his privations after all excuse for them has passed away. If half the money spent in the State for Liquors and Tobacco were devoted to making dwellings comfortable and supplying their tables with fruits, \&c., the whole people would be happier and better.

A few words as to the cities:

I missed Austin, the State capital, by an accident and an all-night thunderstorm, which stopped me at Giddings, the present western terminus of the Texas Central Railroad, leaving 55 miles (rapidly diminishing) of staging over tracks which might be converted into roads were not the railroads so soon to supersede their most important use. As they are, 18 hours are usually required to traverse them ; but the stages which I didn't take at Giddings had not reached Austin two days after they started-the usually dhy water-courses having been converted by the rain into raging torrents which could not be crossed. Had I duly reached Austin, I hoped thence to make New-Braunfels, the nucleus of the principal German settlement in Texas and the seat of considerable manufacturing industry, and thence (if possible) San Antonio, the Capital and price of Western Texas, which boasts a population of 15,000 , with a tendency to rapid increase. Within two years, it will have been reached by the Inter- 
national Railroad from Austin and the north-east, and by that from Columbus, connecting it with Houston, Galveston, New Orleans, and Mobile; when its population will go up like a balloon to 50,000, if not higher. I am assured that they have good (though hard) spring water near the Capital and all these Western cities, which made it harder for me to turn back without reaching them.

Galveston seemed to me a little nervous lest the railroads now in progress should draw off her trade and leave her hard aground; which does not to me seem probable. Her relative importance may be reduced by them, but $\mathrm{I}$ judge that her actual trade will be largely increased. She has by far the best harbor in the State, with a primacy already achieved which will not lightly depart. I profoundly trust that she may soon and forever lose the profit she now derives from the importation and distribution of all the Flour and most of the Hams and other Pork consumed in the lower half of the State, drawing her own supplies from Northern Texas by rail instead; but Texas will always grow Cotton for export, and most of it will find its way to the North and to Europe through Galveston. Sugar will be made on the coast and distributed throughout the interior via Galveston; while Beef, Hides, Tallow, and ultimately Corn, Hams, Wool, \&c., will be exported thence, and many cargoes of Dry Goods, Hardware, \&c., be received and distributed in return. 'The vessels that take away the exports of Texas will come freighted -with imports. As her manufactures expand, she will require many ship-loads per annum of Coal from the Ohio before she can have achieved easy access to her own. Galveston must devote part of her wealth to making advantageons connections with all the great railroads that cross or reach the State; she must work hard to improve or at least maintain the capacity and accessibility of her harbor; and she must resolutely fence out the Yellow Fever by internal purification as well as external vigilance, and her future is secure.

Houston is now intent on so rleepening and straightening her Bayou that any vessel that can pass the bar at Galveston may discharge at her wharves, 50 miles inland, and so much further on the way to a large majority of Texan consumers. It is a spirited enterprise, in good hands, well backed, and its early success fully assured. It will increase the trade of Houston, but will not aggrandize her at Galveston's expense to any such extent as is expected. Most of the vessels that cross the bar at Sandy Hook might go up to Newburgh or Poughkeepsie; but they generally conclude to stop 
at New-York. A correct history of the origin and daily growth of our city of Hudson might be read with profit by Houston and with comfort by Galveston. They are two smart, young, growing communities, and not half so much in each other's way as they fancy. If Galveston stood twenty feet higher above the surface of the Gulf, Houston rejoiced in a few hills and ledges, and each of them were blessed with water to drink other than as it falls from heaven, I should like them even better than I do. As she is, Houston is one of the loveliest cities that ever rose from a level plain, and stands so high above the Bayou that she may cleanse and keep sweet if she only will.

It remains only to say that, though the early Spring was rather backward and cold, followed by a dry time that stopped vegetable growtlı, the heavy rains of the last ten clays have "made the crops," as they say-Corn especially, which is planted more extensively than ever before. The foremost fields are now in tassel; many are six feet in average hight; and the promise of a large yield is almost a certainty. Cotton is generally small as yet, but looks well. Other crops (except Beef) are of little consequence. The general expectation is that Texas will produce far more Food in 1871 than in any former year, with less Cotton only because her planters have learned in the clear school of experience that those who till the earth can rarely afford to buy the bulk of their own food.

H. G.

\section{THE CONDITION OF THE BLACKS.}

[EDITORIAL CORRESPONDENCE OF TIIE TRIBUNE.]

Near Vicksburg, Miss., June 1.-D During the last three weeks, I have made a point of inquiring of all classes as to the condition, conduct, and prospects, of the Freedmen throughout the Gulf States. The substance of the testimony thus elicited I sum up as follows:

The planters who were formerly slaveholders have uniformly assured me that their ex-slaves are working better than they expected, and better this year than ever before. I cannot recollect a single dissent from this averment. Most of the old plantation hands either rent lands, paying so much Cotton per acre, or they work them on shares-say, half the crop when they find their own team and seed, and one-third when these are found by the land-owner. And it. 
has been found far more satisfactory to divide the crop at the ginhouse or at the depot, letting each market for himself, than to have the land-owner sell it in bulk and account to the cultivator for his share of the proceeds. The negroes, keeping no accounts and not very careful in their habits, usually found, on settlement, that they had eaten up their crop while it was growing, and were often in debt after it had been sold and accounted for. No doubt, they were sometimes cheated; but, even when they were not, they supposed they were. Especially when, as in 1866 , the crop was a failure, and their share of it did not repay the land-owner his advances, they conld not understand that, while "old master" had all there was, they had less than nothing. The system was bad, so its results were evil. It is far better where they have no credit, no advances, and struggle through the year as they can, so that their share of the crop, large or small, is all their own when it is ready for sale. On the crop of 1869 , those who worked on this basis generally made money; on that of 1870 , which sold much lower, they made little or nothing; this year, I am assured, they generally grow Corn as well as Cotton, hoping to make their own bread and meat, and leave their Cotton clear. Some will succeed in this; others will fail ; but, taken in the average, I judge that the Freedmen of the Cotton States are this day in as good circumstances as the Hired Workers who till the soil of any European country. And I am confident that the plantation laborers are rarely or never in want of employment or of homes. If there were profligate, idle, pilfering fellows among them, they have drifted away to the cities, or to some other country than this. There is no place for such on plantations; and very few of them could stay there if they would.

The old slaveholders, on whose testimony I have mainly relied thus far, add that the Black women are not doing so well as the men, but are widely intent on finery and idleness. The children (the planters add) rule their parents, and do little or nothing; so that, when this generation of field-hands, trained to steady work as slaves, shall have died off, matters will have changed for the worse. In opposition to this, I proffer the testimony of my eyes. To say that I have seen many more Black women than White persons plowing and hoeing in the Corn, Cotton, and Cane-fields of Louisiana and Texas, would be saying little; I am sure I saw half as many Black women as Black men working the crops; and in many cases father, mother, and one or two children, were at work together. On 
the whole, I must adjudge the question "Will free niggers work?" satisfactorily answered. The Four and a Quarter Million bales of Cotton grown in the United States in 1870 are not to be gainsayed.

On another point, the testimony of the old masters is less assuring. They tell me that their ex-slaves spend their earnings unwisely, improvidently; often squandering in a month the hard earnings of a year. One planter instanced the case of a "boy," who recently bought at once seventeen "Shoo-Fly" boxes, price $\$ 1$ each; their aggregate contents being worth perhaps $\$ 5$, and consisting of candies and showy knick-knacks, with a silver half dollar perhaps in every fifth box. The evidence to this effect is so positive and consistent that I cannot doubt its general truth. The ex-slave, ignorant and simple, finding himself for the first or second time possessed of $\$ 100$ to $\$ 300$, the price of his crop, is too apt to fool it away in purchases that wisdom would shun and reason must condemn.

The Blacks themselves, through such as I have interrogated, give far more cheering testimony. They admit that fools as well as rogues are found among them, as among other races; but they insist that the great majority are saving as well as earning. They assure me that many are buying lands; others accumulating money in the Freedmen's Savings Bank with intent to own homes at no distant day; and that nearly all are doing better from year to year. They say that most of those who own no lands own nules and plows, and are steadily learning to spend their money wisely or save it carefully. I have conversed with no Black who was not hopeful and conficent as to the future of his race. The "carpetbaggers," so called, of course- confirm the testimony of the Blacks. Some of these are good and true men; others aim to be particularly good to themselves. At the worst, it may be fairly urged in their behalf that the blind obstinacy and dogged refusal of the planters to recognize accomplished facts rendered them a necessary evil.

The ancient aristocracy of the South remind me forcibly of the Federal squirearchy of our country after Jefferson's election as President. Instead of studying the new situation and seeking to master it, they content themselves with endless and fruitless complainings. They lament the sway of the "carpet-baggers" over their late slaves, but take no effective measures to counteract it. Rogues as some of the "carpet-baggers" are, they are all zealous for the education of the Blacks; while the submerged aristocracy grudge every penny assessed on them for building school-houses and pay- 
ing teachers, as though it were to be thrown into the sea. The noblest, purest, most intelligent women of New England, who have conne down here to teach Black children, are shunned and banned by the aristocracy as though they were camp-followers of Sherman's army, and, being thus doomed to associate only with Blacks and live with them, are actually charged with this as a betrayal of low tastes, when it was the dictate of stern necessity. I apprehend that the land-owners will in time be impelled by their hate of "carpet-baggers" to change their course, and seek a cordial understanding with the Blacks; but they are not yet in the mood; and the longer they hold off the more difficult the task will prove.

H. G.

THE CONDITION OF THE WHITES.

[EDITORIAL CORRESPONDENCE OF THE TRIBUNE.]

Menphis, Tenn., June 3.-_ Are you not satisfied that the South has no desire that Slavery be reëstablished?" I have often been asked. I answer, I am entirely confident that no considerable number of the Southern people either expect or purpose to reënslave their former chattels. They no more expect that than the faded dandy of fifty full years expects to awake to-morrow morning radiant in the pink-and-white bloom of one-and-twenty-no more than the toper, who has broken his jug and seen the thirsty sand swallow the last drop of its precious contents, expects to get drunk to-morrow on that squandererl liquor. None know better than the great body of the Southeru Whites that the reënslavement of the Freedmen is a moral impossibility.

But, if you mean to ask, "Would the ex-slaveholders choose to have their former slaves restored to them as chattels, if they could?" I answer that I am very thankful that the temptation is mercifully withheld. Wise and thoughtful men there are among them who sincerely, profoundly rejoice that American Slavery is dead beyond the hope of resurrection; but these are not the majority. I am confident that two-thirds of the men, with nine-tenths of the women, who formerly composed the slaveholding caste, would this day give half their houses and lands to have their slaves back again, just as they possessed them in 1860 . They sigh for the good old 
times when every "nigger" obeyed orders without dreaming of resistance or demur, and without expecting any pay. They consider themselves robbed by Emancipation, and would like their "property" back again or its value in some equivalent. It goes against the grain with many of them to bargain with their late chattels for service, and be sued if they do not fulfill their contracts. Their instincts, their training, their habits, are shocked by this, just as yours wonld be if your horse cited you before a court and compelled you to show cause for not paying him ten dollars per month for last year's service.

Then the very general complaint that "we can't control our labor" has a very real foundation. Under the old régime, the slaves had their holidays and their easy times; but, when the Cotton-tields had been filled with grass during three or four rainy weeks in May, wherein little could be done, all hands were called out at daylight so soon as the soil was fit for plowing, and kept hard at work all the bright hours till the crop was "laid by." Again, when the picking season commenced, all hands-men, women, and childrenwere called into the fields, and kept at work from daylight till dark, till the crop was secured. If any lagged or shirked, the whip speedily brought them to their bearings. All this is changed by Emancipation. Mien talk of so many hours to the day's work; women and children are apt to shun field-work; so a given "force"-say twenty families-will not pick so much cotton in the month as they did ten years ago. And nearly every negro aspires to be the master of his own time, and either rent land or work it on shares, in preference to hiring out by the month or season. Perhaps this is best for all concerned; but it sadly dwarfs the planter's consequence, and in most cases his profits also. He does n't like it: can you wonder?

And the change bears much harder on his wife. She had her labors and her cares under the old system: she was no idler, no trifler; her duty and her interest combined to render her physicianin-ordinary and head-nurse to her Black dependents; and she ofter gave anxious days and nights to a struggle with disease at a slave's bedside. But cooking, washing, and other house-work, she was never bred to; and the fall of Slavery threw them all upon her at a moment's notice, requiring her at once to do them and to learn how. Even when ex-slaves remained with her as hired servants, they were no longer docile and obedient as of old, when it was an envied privilege to serve in the big house rather than plow or pick 
in the fields, and the whip was always in reserve in case of need. Thus Einancipation has borne heavily on the wives of the old aristocracy, and (not being politicians) they do not even affect to welcome the change. Many of the wisest and most resolute among them have learned to do their own work, with their daughters' help; some have obtained White help, mainly of foreign birth; others are doing with hired Black servants, but most of these get on badly. Thus the female aristocracy of the Sonth are still averse to the great change they have witnessed; and years must pass before they can be reconciled to it.

I learn with great satisfaction that there is a decided improvement manifest among the "poor Whites." These formed, under Slavery, the most hopeless class in the South. Courted by the aristocracy for their votes, flattered with their rank as members of the dominant caste, allowed to build their shanties on the outskirts of the great plantations, and to breed and train dogs to hunt runaway slaves in the swamps and denser forests, they grew up unlettered and inceligions, hunted and fishec half their time, grew a patch of corn on sufferance, had a pig running in the woods, and lived a thriftless, aimless, worthless life. They were far more fanatical in their devotion to Slavery than the slaveholders, who seldom defiled their hands with the mobbing of an Abolitionist, since the "poor Whites" were too ready to take the job off their hands. For some time after the collapse of the Rebellion, these spent most of their time idling at the cross-roads store or some convenient grog-shop, cursing the Yankees and wondering " why the d- niggers do n't go to work;" but of late a change is apparent. Certainly, there are idle, trifling "poor Whites" still, as there are equally worthless Blacks; but they are fewer than they have been, and growing fewer day by clay. They do not work so resolutely, so persistently, as do their counterparts at the North; but work is no longer disreputable, and many who did not average a fair day's work per week under Slavery do three or four days' work per week under Freedom. The "corn-crackers," "sand-hillers," "clay-eaters," \&c., of the last generation, will be unknown as a class after this century.

That those who struggled and fought for Secession generally believe they were right in so doing, I cannot doubt. Jefferson Davis's late speeches fairly express their average convictions and feelings. But, while they still affirm the right of Secession, I am satisfied that a majority of them believe its practical assertion was 
unwise and inexpedient. They hold that they should have made their late struggle in the Union, not against it-under the flag of our fathers, not that of the Stars and Bars-in ostensible defense of the Federal Constitution, not in resistance to its authority. They purpose to renew the fight, but not with gun and saber. They expect to regain as Democrats through elections the power they lost as Rebels through war. They herein evince that wisdom which profits by the lessons of experience. Here and there a hot-head may talk of renewing, at some more auspicious season, the struggle for an independent Confederacy; but the great majority have had enough of war. I conclude that another Southern Secession is all but impossible.

And, while a bitter spirit is cherished by many, I feel sure that the number who acquiesce, if they do not absolutely rejoice, in the restoration of the Union, is daily increasing. Thousands liate the "carpet-baggers," with their alleged corruptions and spoliations, who protest that they do not hate the Union. They persist in a clamor against what they call "nigger equality" (but which means Negro Enfranchisement, Negro Education), which precludes their swaying the Negro Vote as they otherwise might and would; but they will seek to coerce enough of it into roting the Democratic ticket to give them a majority of the Southern Electoral Votes for next President. But the Blacks grow year by year more independent in fact as well as feeling; and it will neither be easy nor safe to repeat the terrorism whereby Georgia and Louisiana were made to vote for Seymour in 1868. Should the South show an anti-Republican majority in 1872 , it will be a consequence of injudicious appointments and removals, of actual or reputed prodigality in legislation or in office, or of terrorism and constraint exercised over the voters, and not a decision of the people on the questions which vitally difference the two parties.

That the South is steaclily recovering from the calamities and losses consequent on our late Civil War, is very obvions. The process might be more, rapid, but could hardly be more substantial. The cattle and swine which were eaten up during the Civil War are being steadily replaced, and are already twice or thrice as numerous as they were six years ago; lands are going back into cultivation which have long lain waste and idle; farm buildings are undergoing renovation; cities and villages, are extending their borders; factories and furuaces are widely projected, and some are 
in process of construction. It were irrational to expect that all the bitterness engendered by twenty years of sectional collision, including four of bloody war, should be effaced in a day, and of course it is not; but the tendency is right, and Time will exert its healing influence if no untoward event should interpose to prevent it. With a mingling of firmmess in upholding the right, with kinchess to those who were miseducated into wrong, the re-cementing of the Union will be thorough and enduring.

H. G.

\section{RECEPTION OF MR. GREELEY, N. Y., JUNE 12 TII.}

Horace Greeley was welcomed at the Lincoln Club-Rooms, in Union Square, by a large number of friends who were assembled under the auspices of the Union Republican General Committee, and who severally congratulated him upon his safe return from his journey to the far South-West, and through the Lower Mississippi Valley. The rooms were profusely decorated with flags and flowers, and tables well provided with refreshments were set. A large oil-painting of $\mathrm{Mr}$. Greeley occupied a conspicuous place in the main room, and in the others were various photographs and lithographs of him. A plaster bust of Mr. Greeley, cast some twenty years ago, also attracted much attention. On the balcony outside was placed a large bust of Lincoln, wreathed in bunting. In the street, in front of the Club-Rooms, a platform was erected for speaking, and around it were assembled, by 8 o'clock, many thousand people. Calcium lights made the scene almost as bright as day.

Among those present in the Club Rooms and upon the platform, were Wm. M. Evarts, Gen. N. P. Banks, D. D. Conover, Marshall O. Roberts, Dr. Geo B. Loring, Lloyd Aspinwall, Gen. P. H. Jones, Gen. Geo. W. Palmer, Gen. John Cochrane, Sinclair Tousey, Waldo Hutchins, Charles Storrs, A. W. Leggatt, Joseph Howe, Wm. P. Richardson, Rufus F. Andrews, Thomas E. Stewart, Gen. H. A. Barnum, Joln V. Gridley, Benj. F. Manierre, Ira O. Miller, Enoch L. Fancher, L. H. Knapp, Geo. F. Coachmon, J. S. Ritterband, Judge Slosson, Geo. P. Bradford, H. M. Williarns, B. F. Mudgett, Geo. H. Van Cleft, Col. Willis, Major Haggerty, Morris Ellinger, C. H. Cooper, Col. Fairman, and others. Mr. Greeley ap- 
peared at a little before 9 o'clock, and was heartily cheered by those in the crowded rooms. After receiving a personal greeting from nearly every one present, he descended to the platform in front of the house. He was received with great applause, and Mr. Enoch L. Fancher, on behalf of the Union Rejublican General Committee, addressed him as follows:-

Mr. Greeley: On behalf of the Union Republican General Committee of the City of New York, and also of many others of your personal and political friends, I have the honor to welcome you home after your journey to a Southern State. We clon't come, sir, with any set form of speech or any mere form of words, but we come to tender our heartfelt congratulations, and to express our gratification at seeing you again among us. We feel that your visit to a Southern State will have an influence beyond your own personal gratification and information; for you, sir, were not only foremost in the support of the Union, in this State, when rebel arms were raised against it, but you were also the foremost champion for peace and pacification in the whole country at large when those releel arms were laid aside. And now we are glad to listen to your words of wisdom and your counsels of peace. On behalf of the Committee-your personal and political friends-you are tendered this compliment, which you see, in this shape-a spontaneous gathering of the people of this city; and we welcome you to our circle-the society you have so long adorned-and to the ferrent friendship of our hearts.

Mr. Greeley was greeted with renewed applause, and responded as follows :-

Mr. Chairman and Gentlemen: It is not your fault, it was not the fault of the Republican party, that the North and South failed to understand each other before they had sacrificed lialf a million of their best and bravest, burying them in bloody and untimely graves. There never was a time when the representative men of the South were not welcome to express their sentiments and enforce their convictions in any city or in any county of the Free North-in St. Lawrence, in Chautanqua, in Onondaga, or in Washington. There the eminent champions of Southern institutions and Southern principles were always sure to find a patient and respectful hearing. And I firmly believe that, if our leading Northern men had been equally free to traverse the South and there advocate boldly and fearlessly the doctrines 
which the North eherished, our terrible Civil War might have been averted. But such was not our privilege. There was no time while Slavery was dominant in the Sonth that any representative Northern man could have traversed the South, and there boldly and openly asserted the convictions of the North. Never! I recollect distinctly that, in that eventful winter of 1860-61, the correspondents of The Tribune, whom we were obliged to keep traversing the Sonth, were uniformily compelled to conceal their business and to deny their views. Brave and true men they were; but they would have been torn to pieces as if by wolves if they had been known as Tribune correspondents. They dared not address their letters to The Tribune office; they had to address them to private individuals in different parts of the City, in order that we might receive them. So, during that momentous winter, I was, for the first time, invited to deliver a lecture in the border city of St. Louis, where there was already a rising Republican party. When I had arrived say within 100 miles of St. Louis-when I was at Springfield, Ill.-I was met by a telegram from leading Republicans in St. Louis, advising me not to come ; my invitation was virtually withdrawn, and I was compelled to return to the North. I was not expected to say one word in St. Louis concerning politics. I was journeying there at the invitation of a literary society to deliver a literary lecture; yet, since now it is said that at that time The Tribune was aiding and inciting the Southern Secession, it may well be remembered that its editor was turned back from a border eity of the Sonth, simply because it was proposed to have him deliver a literary lecture before a literary society. I wish it had been otherwise, and that we could have saved the half million of true and brave men whose lives have since been sacrificed, because the North and South failed to mderstand each other.

Fellow-citizens, two months ago, I, for the first time, received a formal and commanding invitation to visit the extreme South-Western State of our common country. I at first cleclined peremptorily, believing it impossible for me to spare time to make the journey required. But fricnds gathered around me; invitation upon invitation poured w1 and finally leading men of our City-capitalists who were wisely and nobly investing their money in large sums to open up Texas to the world and bring her into free and untrammeled intercourse with the North—these, too, insisted that I should go. They said, "By all means go down to Texas, for in so doing you may render the whole 
country a great service." There were so many of these urgent appeals to me to go there, that finally I reconsidered my determination and consented to go.

Now, fellow-citizens, I hear it suggested that I went to Texas with too much parade and circumstance; that I too often was found making speeches from the platforms of cars and from the balconies of hotels, when it would have been mnch more dignified if I had simply delivered my Address at Houston and returned to you. Well, gentlemen, I fully concur in the justice of that criticism, and should have gladly deferred to it. Though all I did say was said in the hope of promoting a clearer and better understanding between the North and the South, I would have preferred to speak more deliberately and less frequently. But invitations to speak, poured in upon me by rail and by telegraph, were not less pressing than numerous. I could not find time even to acknowledge, much less accept, those invitations: so that a New-Orleans editor was excusable--though I trust not justified--in suggesting that my farming, however indifferent, must be rather better than my breeding. [Laughter.] I answered when I could; I consented when I could; and for the rest I kept silence.

And here, fellow-citizens, allow me to make some reply to a kindred criticism from like friendly sources. It is urged, in several journals, that my name has too often been before my countrymen in connection with office; and I fully concur in that suggestion. If my own choice had been consulted, you know very well that it would not have been so. But I am, to some extent, a public man; I am identified with party contests and party principles; and I am known to have reproved and reproached better men than myself that they shrink from public life, leaving important offices to be filled by second-rate men, because first-rate men will not accept them. I have said this too often and too publicly to be able now to shrink entirely out of sight and refuse to do the very thing which I have required of others. So, then, during the last twenty years, if I recollect rightly, my name has been four times before you as a candidate; once for the Constitutional Convention, in which $I$ for some time earned $\$ 6$ per day and paid $\$ 4$ for my board, and twice as a candidate for Congress: first in the lower district of this City, where I was perfectly certain to be beaten several thousand votes honestly and twice as many dishonestly. Our friends in 1866 saw fit to use my name for Cougress in that dis- 
trict, where I have worked for the last forty years, where I know a great many people, and where whatever I may have of property or business is located. They put up my name and ran me for Congress, giving me all the Republican votes and some more. So, again last Fall, our friends in the Sixth District saw fit-when I was prostrated by sickness and unable to fulfill engagements to speak made for me by the State Committee-to unite on me as their candidate for Congress; and they supported me in the face of twenty-eight hundred Democratic majority in the previous contest. I could not speak to them. I could not even visit them; but I stood in my lot, and shared the fate of my party and its other candidates. Well, gentlemen, there was one other time. In the Fall of 1869, your State Convention met, nominated a most respectable and acceptable State Ticket, and adjourned. My name was not even thought of. But a few days later, consternation was spread by the news that three leading candidates on that ticket had peremptorily declined; so your State Committee was hastily assembled, and saw fit-being obliged to make a second nomination in order not to let the election go by default and give up the Legislature without a struggle-to fill one of these places on the ticket with my name. I was not consulted. I knew nothing of their purpose. I was absent from the City, and only returned after all had been done, to be told, "Don't say a word; you must stand; that is the end of it ;" and I stood.

Now, fellow-citizens, I am not at all grateful to the Republican party for these several nominations. I accepted them, as I accept any public duty that seems to be fairly incumbent upon me; and I did what I could to secure the success of the ticket on which my name was printed. I am very grateful to those geuerous and gallant Republicans who, in the face of certain defeat, rallied around me and gave me a hearty support, rumning my name in each case a little ahead of the average of iny ticket. For that support, I am grateful; for the several nominations, not at all.

But, gentlemen, the past is past. "Let the dead bury their dead." I am perfectly willing to pass receipts with the Republican party and say that our accounts are now settled and closer. They owe me nothing for being a Republicau; I could not have helped being one if I had tried; and, being a Republican, it was in my nature to do all I could for the success of that party which embodied and enforced my personal convictions. I was just as grate- 
ful to you as you were to me. I was just as much obliged by your coöperation as you were by mine; and there the matter ends. But for the future, I can say, gentlemen, fully and heartily, that I need no office, I desire no office, and, though I never shall decline any nomination that has not been offered me [laughter], I certainly shall seek no office whatever. I am with you and of you; willing to do my part; willing to bear my share of our responsibilities; but I have work enongh, reasonable pay for it, sufficient consideration, with too much notoriety; and the more quiet and peaceful my remaining days may be, the better I shall be satisfied.

Now, then, I went to Texas to deliver an Agricultural Address at Houston, and I delivered it. That was my work, and it was done. But, on my way down, a Club of Union soldiers now living in New Orleans pressed me to make a speech to them in their club-room, and I did so. I attempted in that speech to vindicate the right of this nation, this republic, to that vast Louisiana territory purchased by her money, and defended by the blood of her sons; organized into States by her Congress, and so marle an integral portion of this American Union. I argued that the southern part of the Mississippi Valley could not possibly wish to be separated from the northern part by two menacing lines of frowning fortresses and hostile custom-houses. I urged-as I always have believed-that never did the people living on the lower Mississippi, in their sober senses, seek to be divorced and alienated from the people of the upper Mississippi; and I affirmed the right of the American people to navigate that great river, from the Rocky Mountains to the Gulf, unembarrassed and unimpeded by any boom across its channel or by any gumboats stationed on it to cause vessels to heave-to for custom-house scrutiny and examination. So I talked, because I so believed.

Then, again, visiting the little city of Columbus, Texas-the only place I did visit on the western side of the Colorado riverI was, about this time of night, while sitting in my hotel, waited upon by a German deputation, who asked me to come over to their club-room and talk to them a little while, they being all loyal Union men. Well, I went over. They had a hastily assembled crowd, and I spoke for half an hour, perhaps, in vindication and explanation of the late great struggles for unity in this country and for nnity in Germany; for the defense and protection of these two great nations in their rights of territory and of nationality. I 
argued, as well as I could, that, thongh some men honestly believe that our struggle and the trimmph therein of the National cause will tend to despotism on this continent, and that some so hold with regard to the German triumph in their great struggle, I, on the contrary, believe that the ultimate tendency and result of these two great consummations will be the promotion and advancement of liberal ideas and institutions alike in the Old World and the New.

Well, gentlemen, as I was leaving Texas, a pressing invitation was given me by the Republicans of Galveston to make a speech to them on the last night I spent in their State; and I acceded to their request. I tried before them to vindicate the North against the charges made against her in the South, and to prove that the North did not make war on the Sonth (as too many Southern people still believe she did). I tried to show them that the war was commenced in the South, by the South-nay, in Texas itself-by capturing, through treachery, the United States Army, and turning its arms and munitions against the flag and against the integrity of our country; and that, all the way through, we stood virtually on the defensive, against what seemed to me a most indefensible and wanton aggression. I said what I conld to vindicate the North from the reproach of malignity - of wishing to oppress or plunder or cripple the South; and tried to make my Sonthern countrymen believe that we were all Americans, and all together interested in and striving for the prosperity and the growth of our whole widely-extended country. [Applanse.] Such was my theme at Galveston.

Well, gentlemen, I have heard it objected that, in my speech at New-Orleans, I asserted that, if there had been Universal Ammesty four years ago, there would have been no Ku-Klux in 1871. I do not think I said exactly that; but I did say that I regarded the policy of excluding from office the leading men of the Sonth as a very great mistake, and a very great injury to the National canse and to the Republican party. I said no more than Gen. Sickles had said in substance four years earlier, when he was Military Governor of South Carolina, and declared that he was erippled and enfeebled in his efforts to govern that State well by the faet that her best men, her most intelligent men, her most considerate and conservative men, were not available to him as magistrates, because of an exelusion whereof Andrew Johnson was the anthor. He said, "I cannot gov. 
ern South Carolina as well as I conld if I were able to choose her best men to help me, instead of her second-best." I am entirely of that conviction. I believe it was a mistake, when you allowed a million Confederates to vote for Members of Congress, to deny them the right to rote for just such men as they preferred. I believe their first-rate men would be safer and more useful in Congress than their second-rate men-better for us and better for their Country. $\left[\Lambda_{\mathrm{P}}\right.$ plause.] So I argued, because I so believed; and still I say that, if the men were allowed to represent the Sonth who express the sentiment of the South-if the Toombses, Wises, and Wade Hamptons had been allowed to go to Congress, and had been sent there four years ago-the Republican party would have been a great deal stronger and Reconstruction very much further advaneed and more certain than it is to-day. [Cries of "Bravo," and apllause.] Why, gentlemen, whenever one of these extreme men say anything, you see it canght up and carried all over the Union in the very journals that insist on keeping those men out of Congress and in positions where their words earry with them the least possible weight. If their words are so beneficial and pregnant to us, why not let them speak where the whole country will hear them? [Applause.]

But I have been asked, "Are there any Ka-Klux down South ?" Yes, gentlemen, there are. They didn't come up to me and tell me they were Ku-Klux very often. They didn't undertake to perform their delicate operations upon me. I should have had very much more respect for them if they had. [Great laughter.]

I am moved with profound disgust when I think of these men, covering thenselves with second-hand calico, masking their faces, arming themselves to the teeth, and ricling around to the cabins of poor, harmless negroes, dragging them from their becls, and whipping and maiming them until they are compelled to swear they will never again vote the Republican tieket. I hold that to be a very cowardly procedure as well as a very base one ; and $I$ hold it to be the duty of the Government of the Union to oppose with all its power and all its force every such execrable outrage as this. Do you tell me that those men are liable to State laws for the assaults and batteries they have committed? I don't doubt it; but I say they are also in substance and purpose traitors to the Government, rebels against its authority, and the most cowardly, skulking rebels ever known to this or any other country. [Applause.]

I hold our Government bound, by its daty of protecting our citi- 
zens in their fundamental rights, to pass and enfurce laws for the extirpation of the execrable Ku-Klux conspiracy ; and, if it has not power to do it, then I say our Government is no Govermment, but a sham. I, therefore, on every proper occasion, advocated and justified the Ku-Klux act. I hold it especially desirable for the South ; and, if it does not prove strong enough to effect its purpose, 1 hope it will be made stronger and stronger. [Applause.]

Why, fellow-citizens, these very men that asked me if I saw any Ku-Klux have themselves read the returns of the last Presidential election in Louisiana, when that State, with 30,000 Black majority on its registers, was made to vote for S'eymon' and Blair by more than 30,000 majority ; counties which had 3,000 negro voters alone giving three, two, one, and in several instances no vote at all, for Grant and Colfax. Now, friends, you and they know perfectly well that this result was secured by terror and by violence; by telling those Black men, "You shall vote for Seymour and Blair, the enemies of your fundamental rights, or you shall not roteat all, or you shall be killed." That was the way Lonisiana was made Democratic in 1868 ; and that is the way that I. trust she will never be made so to vote again. Therefore I uphold and justify the Ku-Klux law.

Fellow-ciiizens, the Ku-Klux are no myth, although they shroud themselves in darkness. They are no flitting ghosts; they are a baneful reality. They have paralyzed the Right of Suffiage in many counties throughont the Sonth, and have carried States that they ought not to have carricd; but they are not the only enemies to Republican ascendincy in the South.

There is another influenee equally pernicious with theirs, and a great deal more detrimental to the fame and character of the Republiean party. I allude to what are known as the "thieving carpetbaggers." [Applause.] Fellow-citizens, do not mistake me. All the Northern men in the South are not thieves. The larger part of them are honest and good men, some of whom stay there at the peril of their lives, beeause they believe it their duty. Next to the noble and true women who have gone down Soutl to teaeh Black children how to read-nobler there are not on the earth than these, whom a stupid, malignant, dilapidated aristocracy often sees fit to erowd into negro hovels to live, not allowing them to enter any White society because they are teaehing negro ehildren-next to these, who rank as the noblest women in the South, are the honest 
and worthy Northern men, who, in the face of social proscription and general obloquy and scorn, stand firmly by the Republican cause.

There was a nost urgent and special necessity for rigid economy in the reconstructed States of the South, even aside from their impoverishment by war and the disruption of their inclustry by peace. For despotic government has this advantage over free, that its agencies are apt to be simple and chealy. The old Slave governments of the South were thoroughly aristocratic, and they were very rarely corrupt or prodigal. The plunters praid most of the taxes; they decided who should be legislators; and they did not abicle jobbers. Legislative stealing was almost an unknown art among them. Then they had no public support of the poor"; each snbsisted, after a fashion, his own userl-up slaves. The Poor Whites lived or died as they might; and, exeept for the Whites or two or three great cities, there were no publie sehools: and this made government cheap and taxes light.

With Emancipation, came a great change. There was an urgent, demand for free schools, and the school-houses had to he built, to begin with; for the prblic support of paupers, White and Black, and there were no alms-houses; and so with many public institutions. Just when the people were poorest, they were required to bear the heaviest public expense, though only aeenstomed to the lightest. Dissatisfaetion and complaint were inevitable; but every effort should have been made, every nerve strained, to mitigate them by vigorous economy. I regret to say that the reverse was the course pursued in some States by men who rode into power on the artillery wagons of the Union, under the flag of Emancipation.

The publie is often heedlessly unjust. Let a Government hive 10,000 offieial subordinates in power, of whom 9,900 are honest and true men who do their duty faithfully, while barely 100 are robbers and swindlers, the public will hear a great deal more abont the 100 robbers than about the 9,900 true men. The 100 stand out in the public eye-they are always doing something which exposes them to the scornful gaze of the multitude-while the honest and true men pass along silent and unobserved, and nothing is said, very litthe is thonght, of them. All attention is concentrated upon the 100, who are defaulting, and stealing, and forging, and running away.

Well, gentlemen, the thieving carpet-baggers are a mourn. ful fact; they do exist there, and I have seen them. They are fellows who erawlet down South in the track of our armies, gen- 
erally at a very safe distance in the rear; some of them on sutlers' wagons; some bearing cotton permits; some of them looking sharply to see what might turn up; and they remain there. They at once ingratiated themselves with the Blacks, simple, credulous, ignorant men, very glad to welcome and to follow any Whites who professed to be the champions of their rights. Some of them got elected Senators, others Representatives, some Sheriffs, some Judges, and so on. And there they stand, right in the public eye, stealing and plundering, many of them with buth arms around negroes, and their hands in their rear pockets, seeing if they cannot piek a paltry dollar out of them; and the public looks at them, does not regard the honest Northern men, but calls every "carpet-bagger" a thief, which is not the truth by a good deal. But these fellows-many of them longfaced, and with eyes rolled up, are greatly concerned for the education of the Blacks, and for the salvation of their souls. [Great laughter.] "Let us pray," they say; but they spell pray with an "e," and, thus spelled, they obey the apostolic injunction to "pray without ceasing."

Fellow-citizens, the time has been, and still is, when it was perilous to be known as a Republican or an Abolitionist in the South ; but it never called the blush of shame to any man's cheek to be so called, until these thieving carpet-baggers went there-never! [Applause.] They got into the Legislatures; they went to issuing State-bonds: they pretended to use them in aid of railroads and other improvements. But the improvements were not made, and the bonds stuck in the issuers' pockets. That is the pity of it.

"Well," some say, "you have just such thieves at the North." Yes, we have-too many of them! [Applause.] But the South was already impoverished-was bankrupt-without money, without thrift, almost without food; and these fellows went there robbing and swindling when there was very little to steal, and taking the last ten-cent shin-plaster off of dead men's eyes. They were recognized by the late aristocracy not merely as thieves but as enemies. Says Byron's Greek minstrel,

"A tyrant-but our masters then Were still at least our countrymen."

Thus we regard the men who annually rob us at Albany, at Trenton, and at Harrisburg. They do not carry their plunder out of the State when they get any. These fellows do! The South 
was not merely beaten in the late contest; she was profoundly astonished by the result. Her peopie have not fairly got over their amazement at their defeat; and what they see of us are these thieves, who represent the North to their jaundiced vision, and, representing it, they disgrace it. They are the greatest obstacle to the triumph and permanent ascendancy of Republican principles at the South, and as such I denounce them. [Applause.]

"Well, then, do you justify the Ku-Klux?" I am asked. Justify them in what? If they should choose to catch a hundred or two of these thieves, place them tenderly astride.of rails, and bear them quietly and peaceably across the Ohio, I should of course condemn the act, as I condemn all violence; but the tears live in a very sunall orion that would water all my sorrow for then. [Laughter and applause.] But they do nothing like that; they don't go for the thieving carpet-baggers; but they skulk around wretched cabins, and drag out inoffensive negroes, to lash and torture them, merely for standing up for their rights as men. For this, I do execrate the Ku-Klux. I say they are a disgrace to Southern Clivalry; and they would be drummed out of the South if there were any true Chivalry there.

But it has been reported very widely that at Vicksburg, addressing a mainly Southern audience, and trying to awaken in them something of the sentiment of nationality and patriotism which burns in a true American bosom, I said that I trusted the time would come when we of the North wonld honor Lee and Stonewall Jackson. I did not say that. What I did say was that I hoped the time would come when Americans North, as well as Americans South, would feel a just pride in the soldierly achievements and military character of Lee and Stonewall Jackson, just as I trusted the late Confederates would learn to feel a patriotic pride in the achievements of Grant and Sherman, and Thomas and Sheridan. I said that, or something very like it. Possibly, you are not willing to go so far as that. Very well, there is no hurry. Take your time; I can wait. Yes, I can wait.

\section{THE NEW DEPARTURE.}

But, gentlemen, my roice fails, yet I want to say a few words about the New Departure. When men are in a bad fix, I reckon they had better depart from it; and I fully justify those Democrats who have determined to depart from the foolish old busi- 
ness of running their heads against a stone wall. If I were there, I should depart; and I think it well for them to do it; and, since they do it, I am not inclined to criticise the manner too severely, nor to judge them too harshly. I have made a rule for some time never to conjure up a bad motive for a good action. 'They are where they onght not to be; they propose to depart; and I think they should.

Our Ohio friends do not take quite so charitable a view of the New Departure as I do. They say there was a particularly rough eharacter once, who was noted for violating the Sabbath, among other bad deeds. But finally he became converted, "got religion," and joined the church. All right. One day, a gentleman eame along and asked a neighbor of his, "Do you see any great change in Nokes since he joined the chureh ?" "O yes, very great; he used to go out chopping Sunday mornings with his ax swung over his shoulder ; now he carries it under his coat." [ Laughter.] Gentlemen, I am very glad that the Democratic party has taken off its shoulder the ax which it has wielded so many years in deadly hostility to the rights of the Colored race. I am glad even if it has put it under its coat; but I hope it will think better of it and put it back into the wood-honse, and meet the Blacks with open hands, saying, "TVe are going to treat each of you just as you shall deserve to be treated, no matter what is the color of your skin." I do believe they mean this - the most of them. I believe they mean hereafter to wear their Democraey somewhat more than skin-deep. At any rate, $I$ shall urge and encourage them to do so.

Fellow-citizens : I would not make too much of this New Departure. I do not understand these gentlemen even to profess any penitence for their past warfare against the Equal Rights of Mcn. I don't understand them even to promise that they will never renew that warfare. I only understand them as pledgerl to this extent: They admit that the three Republican anendments to the Federal Constitution are now a part of that Constitution, and, while they shall remain there, they must be obeyed. That I understand to be the extent of the New Departure; and I deem it worth a great deal. So long as they admit that these Amendments are in, I shall feel pretty sure that they are not likely to get them out. I shall rest content that the rights of all men, being eitizens of the United States, are safe under the guaranties of the Federal Constitution.

Twenty-five years ago, J stood at the polls of the XIXth Ward 
of this city all one rainy, chill November day, peddling ballots for Equal Suffrige. I got many Whigs to take them, but not one Democrat. Again in 1860-not eleven years ago-I again stood at my poll all day, and lianded out the same kind of vote; and I do not remember that a single Democrat took one. Some Republicans, even, would not take them; but no Democrat would.

I believe in Human Progress. I believe that men are rather wiser and better to-day than they were twelve years ago; and here is proof of it. It is not two year's since our. Democratic State Legislature withdrew the consent given by its Republican predeces'sors to the XVth Amendment, and, hy a party rote, so far as New York could do it, they tried to defeat that amendment. Now, we have a New Departure. Was it not high time? I think it was.

Fellow-citizens : I am weary, weary, of this sterile strife eoneerning the fundamental principles of republican institutions. I an tired of trying to teach Democrats the A, B, C's of Democraey. I rejoice to know that they lave taken a New Departure; and I tell you that, when they have nnce taken it, it will be a great deal harder to get back to the old ground than to go on. Some one says, "Isn't it going to put the Republicans out of power?" I eannot tell. Immediately, I think not. Mr. Burke well says: "Confidence is a plant of slow growth ;" and I think it will take some time for the penple to realize that the Democrats mean to uphold Equal Rights-some time for their own folks to realize it-a great deal longer to make any Black man believe that they mean it.

I don't anticipate any sudden change in the relative strength of parties, becanse of the New Departure. Ultimately, I think, it will strengthen the Democrats. "Then," one says, "you will go out of power." Yes, we shall some time, no donbt. If it were to be my fate to go out this moment, and every year of my life thereafter to be in the minority, prostrate and powerless, I should still thank God, most humbly and heartily, that He allowed me to live in an age, and to be a part of the generation, that witnessed the downfall and extinction of American Slavery. [Prolonged applause.]

Fellow-citizens: I trust the day is not distant wherein, putting behind us the things that concern the Past, we shall defer to that grand old injumction of the Bible: "Speak to the children of Israc I that they go forward." I an weary of fighting over issues that onght to be dead-that logically were dearl years ago. When Slarery died, I thought that we ought speedily to have ended all tlat 
grew out of it by, Universal Amnesty and Impartial Suffrage. [Applause.] I think so still; and that if the Democratic party shall concede Impartial Suffrage, the Republican party will concede Universal Amnesty; if not, it will have a very short lease of power. So, then, friends, I summon you all, Republicans and Democrats, to prepare for the new issues and new struggles that visibly open before us. In the times not far distant, I trust we shall eonsider questions mainly of industrial policy-questions of national advancement-questions concerning the best means whereby our different parties may, through coöperation, or through rivalry, strive to promote the prosperity, the happiness, and the true glory of the American people. To that contest I invite you. For that contest I would prepare you. And so, trusting that the bloodshed in the past will be a sufficient atonement for the sins of the past, and that we are entering upon a grand New Departure, not for one party only, but for the whole country-a departure from strife to harmony, from devastation to construction, from famine and desolation to peace and plenty-I bid you, friends and fellow-citizens, an affectionate good-night. [Prolonged clieers and applause.] 






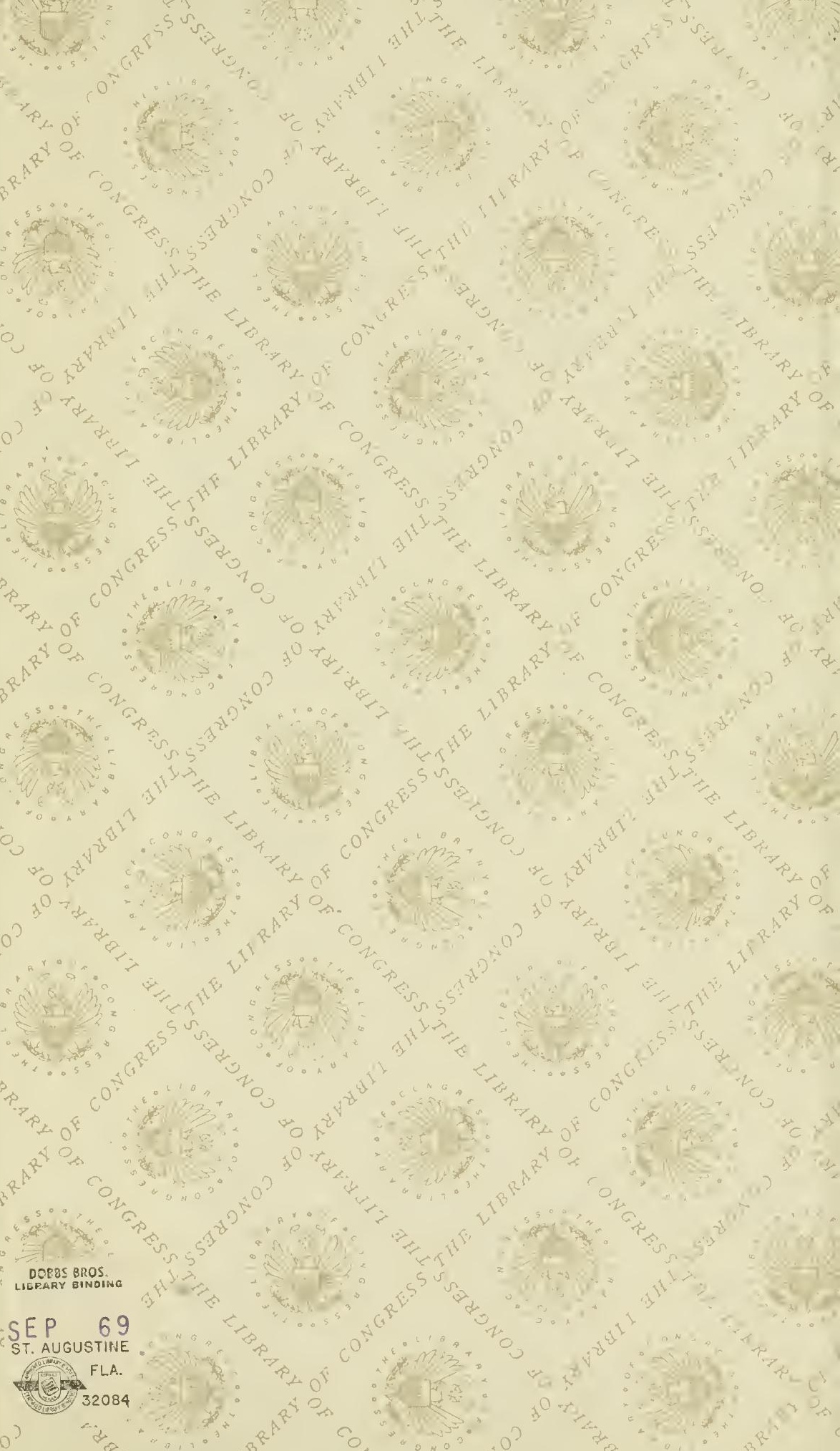




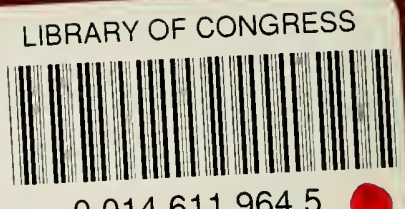
00146119645 